\title{
Morphological and Molecular Identification of Seedborne Fungi in Squash (Cucurbita maxima, Cucurbita moschata)
}

\author{
Marwa Moumni, ${ }^{1,2,3}$ Mohamed Bechir Allagui, ${ }^{3}$ Valeria Mancini, ${ }^{1}$ Sergio Murolo, ${ }^{1}$ Neji Tarchoun, ${ }^{4}$ and Gianfranco Romanazzi ${ }^{1} \dagger$ \\ ${ }^{1}$ Department of Agricultural, Food and Environmental Sciences, Marche Polytechnic University, 60131 Ancona, Italy \\ ${ }^{2}$ National Agricultural Institute of Tunisia, 1082 Tunis, Tunisia \\ ${ }^{3}$ Laboratory of Plant Protection, National Institute for Agronomic Research of Tunisia, University of Carthage, 2080 Ariana, \\ Tunisia \\ ${ }^{4}$ Laboratory of Vegetable Crops, High Agronomic Institute of Chott Mariem, Sousse, Tunisia
}

\begin{abstract}
Squash is one of the most important crops of tropical and temperate regions, and it can be affected by several fungal pathogens. Most of these pathogens infect the seeds, which become an efficient vehicle to disperse seedborne pathogens over long distances, with consequent severe crop losses. The main objective of this study was the identification of the principal seedborne fungi in seeds extracted from 66 samples of asymptomatic and symptomatic squash fruit (Cucurbita maxima, Cucurbita moschata) collected in two countries, Tunisia and Italy. The symptoms of fruit decay were identified and classified according to lesion size. Following the blotter test, 14 fungal species were de-

(3.3\%), and Stemphylium vesicarium (2.3\%). For the fruits from Italy, the most frequently identified fungal species in seed samples were Alternaria alternata $(40.0 \%)$, followed by $F$. fujikuroi (20.8\%), Stemphylium vesicarium (3.0\%), and Curvularia spicifera (2.1\%). Morphological identification was confirmed by molecular diagnosis using the available species-specific primers. Furthermore, specific primers were designed to identify Albifimbria verrucaria, Paramyrothecium roridum, and Stemphylium vesicarium. Application of seed-health testing methods, including such conventional and molecular diagnostic tools, will help to improve seed quality and crop yields.
\end{abstract} tected from the seeds. Seedborne fungi were identified in all fruit samples tested, including asymptomatic fruit. The most frequent fungi from Tunisian seeds were Alternaria alternata $(25.1 \%)$, followed by Stagonosporopsis cucurbitacearum (24.6\%), Fusarium solani (16.6\%), Rhizopus stolonifer (13.3\%), F. fujikuroi (7.8\%), Albifimbria verrucaria
Keywords: Albifimbria, asymptomatic, blotter test, $\beta$-tubulin, detection, diseases of Cucurbita species, EF1 $\alpha$, histone H3, ITS, Paramyrothecium, rDNA, seed-health test, species-specific primers, Stemphylium
Cucurbita L. (pumpkins, squash, and gourds) is a widely cultivated genus in agricultural regions worldwide. According to the Food and Agriculture Organization of the United Nations (2016), a total yield of nearly 20,000,000 tonnes was produced in Asia and Europe, plus 2,932,611 tonnes in the Americas, in 2014. Squash (Cucurbita maxima, Cucurbita moschata) is one of the most important vegetables in tropical and temperate regions. In Italy and Tunisia, the total production of squash was 580,188 and 90,080 tonnes of fresh fruit, respectively, in 2016 (Food and Agriculture Organization of the United Nations 2016).

Cucurbita spp. can be affected by many diseases, including gummy stem blight (GSB), Fusarium fruit rot, and Alternaria leaf spot (Gannibal 2011; Keinath 2011; Mehl and Epstein 2007). GSB (foliar symptoms) and black rot (BR) (fruit symptoms) are caused by three Stagonosporopsis species: Stagonosporopsis cucurbitacearum (Fr.) Aveskamp, Gruyter \& Verkley [anamorph Phoma cucurbitacearum (Fr.) Sacc., syn. Didymella bryoniae (Fuckel) Rehm]; Stagonosporopsis caricae (Syd. \& P. Syd.) Aveskamp, Gruyter \&

${ }^{\dagger}$ Corresponding author: G. Romanazzi; g.romanazzi@univpm.it

Funding: This study was supported by a fellowship from the Institution de la Recherche et de l'Enseignement Supérieur Agricoles (IRESA), Tunisia; by the Ministry of Agriculture and Water Resources, Tunisia; and by Marche Polytechnic University, Italy (project "Detection and molecular characterization of seedborne fungi").

*The $\boldsymbol{e}$-Xtra logo stands for "electronic extra" and indicates that one supplementary table is published online.

The author(s) declare no conflict of interest.

Accepted for publication 23 December 2019.

(C) 2020 The American Phytopathological Society
Verkley (syn. Mycosphaerella caricae Syd. \& P. Syd.); and Stagonosporopsis citrulli M.T. Brewer \& J.E. Stewart (Stewart et al. 2015). GSB and BR are the most important diseases of cucurbits. Under conducive climatic conditions for the disease, which occur especially in warm and humid environments, severe outbreaks can cause 15 to $50 \%$ yield losses, lead to rapid death of the cucurbit plants, and reduce yields (Boughalleb et al. 2007; Keinath et al. 1995; Yao et al. 2016; Zitter and Kyle 1992). Pumpkin and winter squash are particularly susceptible to BR (Brewer et al. 2015), where the seeds can become infested or infected through flower and fruit infection (de Neergaard 1989).

Fusarium fruit rot is caused by Fusarium solani f. sp. cucurbitae W.C. Snyder \& H.N. Hansen (Fsc) teleomorph Nectria hematococca Berk. \& Broome. This pathogen can infect the seeds and can thus be spread over long distances (Boughalleb and El Mahjoub 2006; Farrag and Moharam 2012). Mehl and Epstein (2007) reported a significant relationship between infections of $F$. solani f. sp. cucurbitae in pumpkin fruit tissue and incidence of infected seeds. Fusarium fruit rot is an economically important problem for pumpkin growers, with $30 \%$ of fruit reported as infected in California in the United States (Mehl and Epstein 2007). In the field and greenhouse, Fusarium spp. can cause important yield losses, which may reach $80 \%$ (Blanco and Aveling 2018).

The genus Alternaria can affect several crops during their growing stages and after harvest (Kgatle et al. 2018; Mamgain et al. 2013). Alternaria cucumerina and Alternaria alternata are pathogens of cucurbits, and they can cause severe crop losses (Gannibal 2011; Vakalounakis 1990). Furthermore, Alternaria brunsii has also been detected on seeds of Cucurbita maxima (Paul et al. 2015). Moreover, within the Cucurbitaceae family, leaf spot diseases caused by seedborne pathogens such as Pleospora herbarum (anamorph Stemphylium vesicarium), Paramyrothecium roridum, and Albifimbria verrucaria can result in significant production losses (Fish et al. 2012; Petzer 1958; Sultana and Ghaffar 2009). All of these are necrotrophic fungi that can infect cucurbits and can be transmitted by seeds. Furthermore, the obligate biotrophic fungus Pseudoperonospora cubensis is a major pathogen of cucurbits; it can be fruitborne, seedborne, and seed 
transmitted in butternut gourds (Cucurbita moschata) (Cohen et al. 2014). Low percentages of seed infection can still result in severe crop losses (Mancini et al. 2016; Vannacci et al. 2014; Walcott et al. 1998).

Seeds represent a particularly efficient vehicle for introducing and spreading seedborne pathogens over long distances into new niches (Ahmad et al. 2016; Elmer 2001; Özer and Coşkuntuna 2016; Pellegrino et al. 2010). Therefore, early detection of seedborne fungi is a key step to prevent introduction of infected seeds, to use high standard quality of seeds, and to define integrated disease management strategies (Majumder et al. 2013; Mancini and Romanazzi 2014; Yao et al. 2016). Conventional methods for seed-health testing include the blotter test, which promotes mycelium growth and formation of fruiting bodies on the seed surface, to allow pathogen identification under the microscope (Tsopmbeng and Fomengia 2015). The main problem related to the presence of saprophytic microorganisms on the seed surface can be easily bypassed through surface decontamination of seeds (du Toit et al. 2005; El-Nagerabi and Elshafie 2001; Rodrigues and Menezes 2005). For detection of Stagonosporopsis cucurbitacearum and Alternaria alternata in seeds, the blotter method proved to be more suitable (Ahmad et al. 2016; Lee et al. 1984). However, when these diagnostic methods are used, some fungal species have a high degree of similarity based on their morphology, so distinguishing among these closely related organisms can be difficult, such as between D. bryoniae and Phoma sp. (Keinath et al. 1995), Alternaria alternata and Stemphylium vesicarium (Pryor and Gilbertson 2000), and Bipolaris spp. and Curvularia spp. (Kusai et al. 2015), and also among different Fusarium spp. (Chehri et al. 2011). Therefore, diagnostic methods can also be based on PCR with specific primers to provide high analytical sensitivity to detect and identify different strains of fungi (Babu et al. 2015; Carneiro et al. 2017).

The main objectives of this study were as follows: (i) to estimate the incidence of seedborne fungi identified by morphological features for seeds extracted from symptomatic and asymptomatic squash fruit; (ii) to carry out molecular identification of the seedborne fungi using specific primers for Stagonosporopsis cucurbitacearum, Alternaria alternata, Curvularia spicifera, $F$. solani, and $F$. oxysporum; and (iii) to design species-specific primers for identification of Paramyrothecium roridum, Albifimbria verrucaria, and Stemphylium vesicarium.

\section{Materials and Methods}

Field sites and sample collection. Between 2015 and 2018, 66 samples of asymptomatic and symptomatic squash fruits were sampled in two countries, Tunisia and Italy (Fig. 1). A total of 37 fruit samples were collected from the cultivars Batati, Bjaoui, and Galaoui in Tunisia. These samples were collected between July and November 2015 and 2016 from multiple farms in Tunisia's five major squash production regions. A total of 29 fruit samples were collected from the cultivars Aspen, Butternut, and Naples Long in Italy. These samples were collected between September and October 2018 from different farms and fields in five locations in Italy (Table 1). These squash cultivars from both Tunisia and Italy are local varieties, and they represent the most commonly produced squash cultivars in the respective countries. The fruit samples were taken from seeds produced on farms and from squash seed lots in their respective years.

Fruit sample evaluation. The day after sampling, the fruits were examined for fungal disease symptoms. Fungi were identified based on the presence of clear signs and symptoms. When the symptoms were unclear, isolation was carried out from small pieces of skin that were cut from the squash fruit with symptoms. These small pieces (approximately $2 \mathrm{~mm}$ ) were immersed in 1\% sodium hypochlorite solution for $5 \mathrm{~min}$ and were washed three times with sterilized distilled water; the samples were air dried for $30 \mathrm{~min}$ on sterile paper toweling in a laminar flow hood. The pieces of squash skin were placed on potato dextrose agar (PDA) (42 g/liter; Liofilchem Srl, Roseto degli Abruzzi, Italy) and incubated at $22 \pm 2{ }^{\circ} \mathrm{C}$ for 14 days. The plates were checked daily, and the colonies grown from the pieces of squash skin were transferred to PDA plates to obtain pure cultures. From each fruit sample, the fruit rot, if present, was evaluated according to three levels (Fig. 2): A, asymptomatic fruit; B, infected fruit showing symptoms of rot on the squash skin without reaching the seed cavity; and $\mathrm{C}$, infected fruit showing symptoms of rot that had reached the seed cavity.

Detection and identification of seedborne fungi using classical tools. The seeds were separated, washed with tap water, dried on sterile blotter sheets overnight $(10 \mathrm{~h})$ at room temperature (20 to $24^{\circ} \mathrm{C}$ ), and stored in paper bags at $4^{\circ} \mathrm{C}$ until use. Each sample comprised seeds collected from a single fruit and 200 seeds per sample were tested using the standard blotter method of the International Seed Testing Association (Mathur and Kongsdal 2003). The seeds were surface sterilized using the method of sterilization described above. Two-hundred seeds (10 seeds/plate) were placed on eight pieces of sterile blotter paper that was moistened with $5 \mathrm{ml}$ of sterile distilled water (Whatman no. 4 filter papers; $110 \mathrm{~mm}$ in diameter) in Petri dishes (110 $\mathrm{mm}$ in diameter), and they were incubated for 14 days at $22 \pm 2^{\circ} \mathrm{C}$ with a $12 / 12$-h dark/ultraviolet light photoperiod (TL-D 36W BLB 1SL; Philips, Dublin, Ireland).

Fungus identification was carried out first by examination of the fungal fruiting bodies and the mycelia and spores that developed on the seeds under a stereomicroscope (M125; Leica Microsystems CMS, Wetzlar, Germany). Then the spores, conidiophores, pycnidia, and perithecia of the fungi were examined under a microscope (DM 2500; Leica). To support the initial identification under the microscope, single-spore isolates of each fungus were collected and transferred into PDA in Petri dishes to obtain fungal colonies (Choi et al. 1999). After 8 to 15 days at $22 \pm 2^{\circ} \mathrm{C}$, morphological identification was carried out according to the colors and shapes of the colonies, with measurements of the fungal structures (i.e., pycnidia, perithecia, and conidia) using LAS software (version 3.8; Leica DFC 295), which was applied to 50 units of each structure for each fungus. The fungal species identification was based on the key of Aveskamp et al. (2010), Booth (1971), Champion (1997), Jeon et al. (2015), Lombard et al. (2016), and Mathur and Kongsdal (2003).

Molecular identification of seedborne fungi. DNA extraction from mycelia. On the basis of morphological identification, 93 isolates representative of 14 species isolated were used to set up a protocol of detection based on molecular tools (Table 2). The isolates were grown in PDA Petri dishes until the fungi reach the edge of the plate. A modified DNA extraction by Varanda et al. (2016) was used for these samples. In particular, the mycelia were collected, lyophilized, and ground in $1.5-\mathrm{ml}$ microcentrifuge tubes with the addition of $600 \mu \mathrm{l}$ of extraction buffer $(20 \mathrm{mM}$ of EDTA, $0.1 \mathrm{M}$ of Tris$\mathrm{HCl}, \mathrm{pH} 8.0,1.4 \mathrm{M}$ of $\mathrm{NaCl}, 2 \%$ cetyltrimethylammonium bromide, $4 \%$ polyvinylpyrrolidone, and $0.1 \%$ sodium metabisulfite added just before use) and $60 \mathrm{mg}$ of silicon dioxide (Sigma) to promote mycelium fragmentation. The quality and quantity of the extracted DNA was directly checked on $1 \%$ agarose gels, with evaluation using a BioPhotometer (Eppendorf, Hamburg, Germany). The DNA was finally diluted to $20 \mathrm{ng} / \mu \mathrm{l}$ for further amplification.

PCR amplification using universal primers and sequence analysis. Amplification of the internal transcribed spacer (ITS) and partial sequences of the $\beta$-tubulin (TUB) gene, histone H3 (HIS), the translation elongation factor $(\mathrm{EF} 1 \alpha)$ region, and calmodulin gene in the ribosomal (r)DNA of the isolates (Table 1) was performed. These $20-\mu l$ PCR reactions contained $2 \mu$ l of genomic DNA of the fungal isolate, $10 \mu \mathrm{l}$ of Green Plus Econo Master Mix $2 \times$ (Lucigen, Middleton, WI), and $0.5 \mu \mathrm{l}$ of each primer $(10 \mu \mathrm{M})$. The primers used were ITS1 and ITS4 (White et al.1990) for ITS, Bt2a and Bt2b (Glass and Donaldson 1995) for tub2, CYLH3F and CYLH3R (Crous et al. 2004) for his3, and EF1-728F/EF1-986R (Carbone and Kohn 1999 ) for $E F 1 \alpha$. The PCR reactions were run in a thermal cycler (MyCycler; Bio-Rad Laboratories, Hercules, CA) following the specific parameters published for TUB, HIS, and EF1 $\alpha$. For ITS, the following modifications were made: initial denaturation was at $94^{\circ} \mathrm{C}$ for $3 \mathrm{~min}$, followed by 35 cycles of denaturation at $94^{\circ} \mathrm{C}$ for $40 \mathrm{~s}$, and annealing at $57^{\circ} \mathrm{C}$ for $30 \mathrm{~s}$ for Alternaria alternata (Konstantinova et al. 2002), at $55^{\circ} \mathrm{C}$ for $1 \mathrm{~min}$ for Stagonosporopsis cucurbitacearum, Paramyrothecium roridum, and Albifimbria verrucaria (Babu et al. 2015; Orawan et al. 2014), at $58^{\circ} \mathrm{C}$ for $1 \mathrm{~min}$ for Curvularia 
spicifera and F. solani (Chehri et al. 2011; Dela Paz et al. 2006), and at $57^{\circ} \mathrm{C}$ for $1 \mathrm{~min}$ for Stemphylium vesicarium (Câmara et al. 2002; Dela Paz et al. 2006). Extension was carried out at $72^{\circ} \mathrm{C}$ for $50 \mathrm{~s}$, with a final extension at $72^{\circ} \mathrm{C}$ for $7 \mathrm{~min}$ at the end of the amplification. The PCR products ( $9 \mu$ l per sample) were separated by electrophoresis in $1.5 \%$ agarose gels stained with Red Gel (Biotium, Hayward, CA) and were visualized and captured using an imaging system (Gel Doc XR; Bio-Rad).

Bidirectional sequence analysis was conducted on select amplified isolate fragments at Genewiz (Takeley, United Kingdom) (Table 2). The forward and reverse nucleotide sequences were read and edited using Chromas software (version 2.33) and they were assembled using CAP3 software to obtain a consensus sequence. Bioedit software (version 7.0.0) was used (http://www.mbio.ncsu.edu/Bioedit/ bioedit.html) to cut off 20 to $30 \mathrm{bp}$ of the terminal end sequence. Finally, nBlast analysis (https://www.ncbi.nlm.nih.gov/BLAST/) was carried out to verify the identities of the amplicons.

We selected and used already published specific primer pairs for the molecular identification of Stagonosporopsis cucurbitacearum, Alternaria alternata, Curvularia spicifera, $F$. oxysporum, and $F$. solani, as summarized in Table 3.

Design of specific primers for molecular identification of Albifimbria verrucaria, Paramyrothecium roridum, and Stemphylium vesicarium. The ITS nucleotide sequences for the genera Paramyrothecium, Myrothecium, Albifimbria, Fusarium, Stagonosporopsis, Curvularia, Stemphylium, and Pleospora, available in NCBI GenBank (Supplementary Table S1), were downloaded in FASTA format and aligned using ClustalX (version 1.83) (Thompson et al.
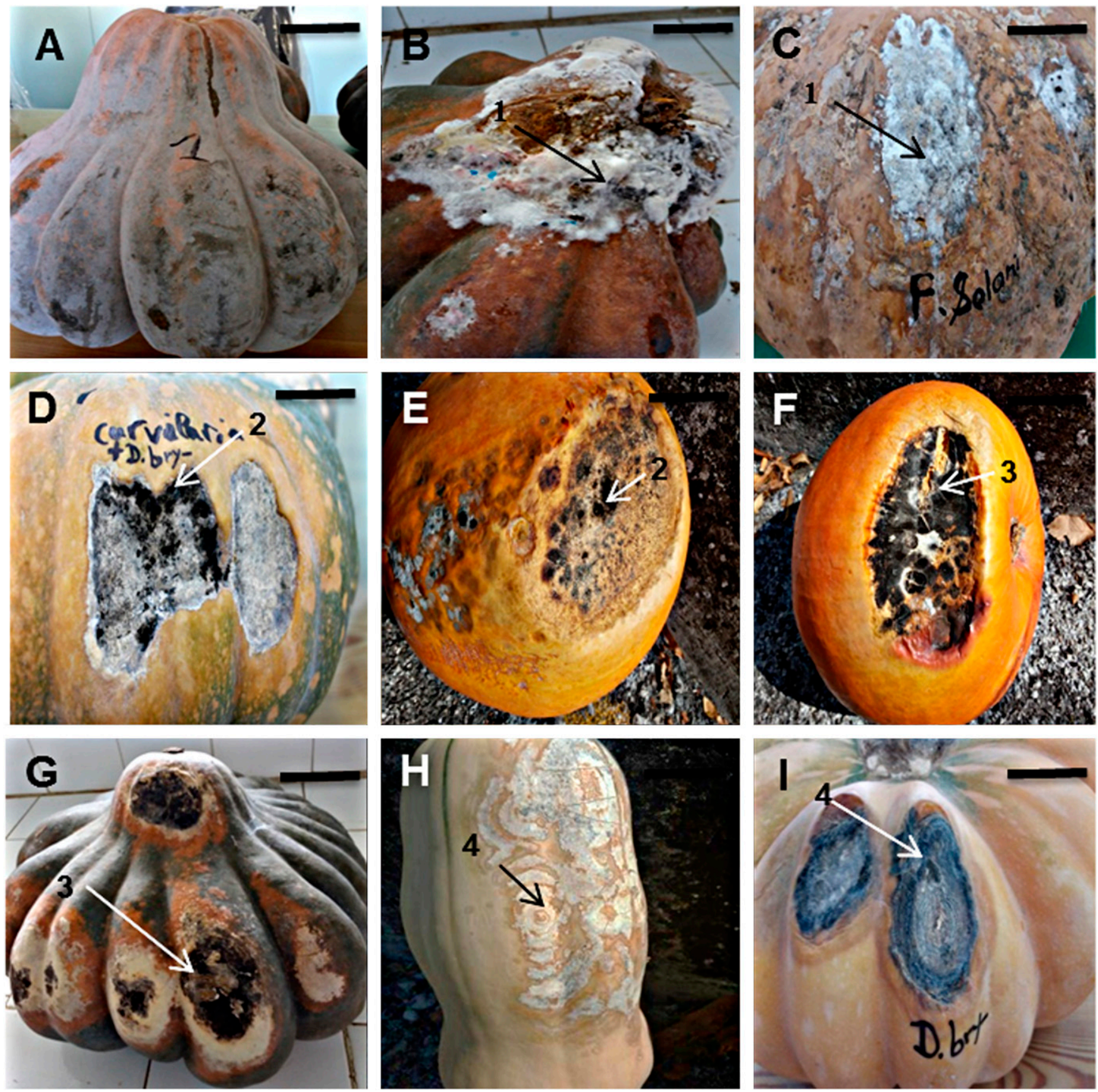

Fig. 1. Fruit rot symptoms on squash fruit. A, Apparently healthy fruit (cultivar Galaoui). B and C, Fusarium rot with white mycelia, caused by Fusarium solani (arrow 1), in cultivars Galaoui and Bjaoui, respectively. D and E, Black mycelia of Curvularia spicifera on squash fruit (arrow 2) in cultivars Galaoui and Aspen, respectively. F and G, Alternaria fruit spot caused by Alternaria alternata (arrow 3) in cultivars Aspen and Galaoui, respectively. $\mathbf{H}$ and I, Black rot caused by Stagonosporopsis cucurbitacearum (arrow 4 ) in cultivars Butternut and Bjaoui, respectively. Scale bars $=5 \mathrm{~cm}$. 
Table 1. Field sites and fruit samples collected from Tunisia and Italy

\begin{tabular}{|c|c|c|c|c|c|c|}
\hline Country & Province & Locality & Fruit sample & Host & Cultivar $^{\mathrm{a}}$ & Year of collection \\
\hline \multirow[t]{37}{*}{ Tunisia } & Ariana & Kalâat El-Andalous $\left(37^{\circ} 03^{\prime} 45^{\prime \prime} \mathrm{N}, 10^{\circ} 07^{\prime} 06^{\prime \prime} \mathrm{E}\right)$ & T34 & Cucurbita maxima & Bjaoui & 2015 \\
\hline & & & $\mathrm{T} 35$ & C. maxima & Galaoui & 2015 \\
\hline & & & $\mathrm{T} 47$ & C. maxima & Bjaoui & 2015 \\
\hline & & & T52 & C. maxima & Bjaoui & 2015 \\
\hline & & & T63 & C. maxima & Galaoui & 2015 \\
\hline & & & $\mathrm{T} 71$ & C. maxima & Bjaoui & 2015 \\
\hline & & & $\mathrm{T} 45$ & C. maxima & Galaoui & 2015 \\
\hline & & & T69 & C. maxima & Galaoui & 2015 \\
\hline & & & $\mathrm{T} 1$ & C. maxima & Galaoui & 2015 \\
\hline & & & $\mathrm{T} 3$ & C. maxima & Batati & 2015 \\
\hline & Siliana & Sidi Hmada $\left(35^{\circ} 57^{\prime} 28^{\prime \prime} \mathrm{N}, 9^{\circ} 32^{\prime} 57^{\prime \prime} \mathrm{E}\right)$ & T8 & C. maxima & Bjaoui & 2015 \\
\hline & & & $\mathrm{T} 4$ & C. maxima & Bjaoui & 2015 \\
\hline & & & T13 & C. maxima & Bjaoui & 2015 \\
\hline & & & T9 & C. maxima & Bjaoui & 2015 \\
\hline & & & $\mathrm{T} 7$ & C. maxima & Bjaoui & 2015 \\
\hline & & & T18 & C. maxima & Bjaoui & 2015 \\
\hline & & & $\mathrm{T} 22$ & C. maxima & Bjaoui & 2015 \\
\hline & & & T14 & C. maxima & Bjaoui & 2015 \\
\hline & Bizerte & Utique $\left(37^{\circ} 03^{\prime} 25^{\prime \prime} \mathrm{N}, 10^{\circ} 03^{\prime} 43^{\prime \prime} \mathrm{E}\right)$ & T6 & C. maxima & Bjaoui & 2015 \\
\hline & & & T16 & C. maxima & Bjaoui & 2015 \\
\hline & & & $\mathrm{T} 38$ & C. maxima & Bjaoui & 2015 \\
\hline & & & $\mathrm{T} 40$ & C. maxima & Bjaoui & 2015 \\
\hline & & & T58 & C. maxima & Bjaoui & 2015 \\
\hline & & & T66 & C. maxima & Bjaoui & 2015 \\
\hline & & & $\mathrm{T} 70$ & C. maxima & Bjaoui & 2015 \\
\hline & & & T81 & C. maxima & Bjaoui & 2016 \\
\hline & Kasserine & Sbeïtla $\left(35^{\circ} 14^{\prime} 00^{\prime \prime} \mathrm{N}, 9^{\circ} 08^{\prime} 00^{\prime \prime} \mathrm{E}\right)$ & T76 & C. maxima & Bjaoui & 2016 \\
\hline & & & $\mathrm{T} 77$ & C. maxima & Bjaoui & 2016 \\
\hline & & & $\mathrm{T} 78$ & C. maxima & Bjaoui & 2016 \\
\hline & & & T79 & C. maxima & Bjaoui & 2016 \\
\hline & & & $\mathrm{T} 80$ & C. maxima & Bjaoui & 2016 \\
\hline & Monastir & Sahline $\left(35^{\circ} 45^{\prime} 02^{\prime \prime} \mathrm{N}, 10^{\circ} 42^{\prime} 44^{\prime \prime} \mathrm{E}\right)$ & $\mathrm{T} 23$ & C. maxima & Batati & 2015 \\
\hline & & & $\mathrm{T} 24$ & C. maxima & Bjaoui & 2015 \\
\hline & & & $\mathrm{T} 26$ & C. maxima & Bjaoui & 2016 \\
\hline & & & $\mathrm{T} 28$ & C. maxima & Bjaoui & 2016 \\
\hline & & & $\mathrm{T} 29$ & C. maxima & Bjaoui & 2016 \\
\hline & & & $\mathrm{T} 30$ & C. maxima & Bjaoui & 2016 \\
\hline \multirow[t]{29}{*}{ Italy } & Ancona & Castelfidardo $\left(43^{\circ} 27^{\prime} 51^{\prime \prime} \mathrm{N}, 13^{\circ} 32^{\prime} 46^{\prime \prime} \mathrm{E}\right)$ & $\mathrm{I} 2$ & C. maxima & Aspen & 2018 \\
\hline & & & I3 & C. maxima & Aspen & 2018 \\
\hline & & & $\mathrm{I} 4$ & Cucurbita moschata & Naples Long & 2018 \\
\hline & & & I5 & C. maxima & Aspen & 2018 \\
\hline & & & I8 & C. maxima & Aspen & 2018 \\
\hline & & & $\mathrm{I} 12$ & C. moschata & Naples Long & 2018 \\
\hline & & & $\mathrm{I} 13$ & C. moschata & Naples Long & 2018 \\
\hline & & & I16 & C. moschata & Naples Long & 2018 \\
\hline & Ancona & Osimo $\left(43^{\circ} 29^{\prime} 00^{\prime \prime} \mathrm{N}, 13^{\circ} 29^{\prime} 00^{\prime \prime} \mathrm{E}\right)$ & $\mathrm{I} 17$ & C. moschata & Butternut & 2018 \\
\hline & & & $\mathrm{I} 18$ & C. moschata & Butternut & 2018 \\
\hline & & & I19 & C. moschata & Butternut & 2018 \\
\hline & & & $\mathrm{I} 20$ & C. moschata & Butternut & 2018 \\
\hline & & & $\mathrm{I} 21$ & C. moschata & Butternut & 2018 \\
\hline & & & $\mathrm{I} 22$ & C. moschata & Butternut & 2018 \\
\hline & & & $\mathrm{I} 23$ & C. moschata & Butternut & 2018 \\
\hline & & & $\mathrm{I} 24$ & C. moschata & Butternut & 2018 \\
\hline & & & $\mathrm{I} 25$ & C. moschata & Butternut & 2018 \\
\hline & & & $\mathrm{I} 26$ & C. moschata & Butternut & 2018 \\
\hline & & & $\mathrm{I} 27$ & C. moschata & Butternut & 2018 \\
\hline & & & $\mathrm{I} 28$ & C. moschata & Butternut & 2018 \\
\hline & Macerata & Recanati $\left(43^{\circ} 24^{\prime} 00^{\prime \prime} \mathrm{N}, 13^{\circ} 33^{\prime} 00^{\prime \prime} \mathrm{E}\right)$ & $\mathrm{I} 29$ & C. moschata & Butternut & 2018 \\
\hline & & & $\mathrm{I} 30$ & C. moschata & Butternut & 2018 \\
\hline & & & $\mathrm{I} 31$ & C. moschata & Naples Long & 2018 \\
\hline & & & $\mathrm{I} 32$ & C. maxima & Aspen & 2018 \\
\hline & & & $\mathrm{I} 33$ & C. moschata & Butternut & 2018 \\
\hline & & & $\mathrm{I} 34$ & C. maxima & Aspen & 2018 \\
\hline & Bari & Monopoli $\left(40^{\circ} 57^{\prime} 00^{\prime \prime} \mathrm{N}, 17^{\circ} 18^{\prime} 00^{\prime \prime} \mathrm{E}\right)$ & $\mathrm{I} 35$ & C. moschata & Butternut & 2018 \\
\hline & & & $\mathrm{I} 36$ & C. maxima & Aspen & 2018 \\
\hline & Campobasso & Baranello $\left(41^{\circ} 32^{\prime} 00^{\prime \prime} \mathrm{N}, 14^{\circ} 33^{\prime} 00^{\prime \prime} \mathrm{E}\right)$ & $\mathrm{I} 37$ & C. moschata & Butternut & 2018 \\
\hline
\end{tabular}

a The three squash cultivars from Tunisia use the local Tunisian names (Galaoui, Bjaoui, and Batati) and represent the squash cultivars that are most commonly produced there. 
1994). The specific nucleotide regions that characterized each fungal genus and the conserved intragenera nucleotide regions were selected to design a new specific primer pair for Albifimbria verrucaria, Paramyrothecium roridum, and Stemphylium vesicarium, respectively (Table 4). The new set of primers that were designed were submitted and validated to Primer-BLAST software (Ye et al. 2012) developed at the NCBI.

After optimization of the reaction mixture, the PCR amplifications were performed in $25 \mu \mathrm{l}$ of reaction mixture that contained $2 \mu \mathrm{l}$ of genomic DNA (about $20 \mathrm{ng} / \mu \mathrm{l}$ ) of the fungal isolates, $200 \mu \mathrm{M}$ of dNTP mixture, $0.5 \mu \mathrm{M}$ of each primer, $1.2 \mathrm{mM}$ of $\mathrm{MgCl}_{2}$, and $1.25 \mathrm{U}$ of Taq polymerase (Promega, Madison, WI). The details of the cycling conditions are reported in Table 5 for each primer pair. PCR was carried out with serially diluted DNA extracted from Albifimbria verrucaria, Paramyrothecium roridum, and Stemphylium vesicarium isolates M144, M123, and P164 (4 × 10 to $4 \times 10^{-5}$ $\mathrm{ng}$ ), respectively, to determine the analytical sensitivity of the tests.

\section{Results}

Fruit symptom evaluation. In the Sidi Hamada area of Tunisia, five fruits showed an infection level of A (asymptomatic fruit), one of B (infected fruit showing symptoms of rot on the squash skin without reaching the seed cavity), and two of $\mathrm{C}$ (infected fruit showing symptoms of rot that had reached the seed cavity), with three fruits with symptoms related to Stagonosporopsis cucurbitacearum and one to Alternaria alternata. In the Kalâat El-Andalous area, two fruits showed an infection level of A and eight of B, with one fruit with symptoms related to $F$. solani, one to Curvularia spicifera, and seven to Alternaria alternata. All of the samples collected in the other three localities of Utique, Sbeitlla, and Sahline areas showed infection levels of A (Table 6).

In the Castelfidardo area of Italy, two fruits showed an infection level of $\mathrm{A}$, three of $\mathrm{B}$, and three of $\mathrm{C}$, with six with symptoms related to Alternaria alternata and two to Curvularia spicifera. In the Osimo area, three fruits showed an infection level of A and nine of B, with eight with symptoms related to Stagonosporopsis cucurbitacearum and nine to Alternaria alternata. In the Recanati area, one fruit showed an infection level of A, three of B, and two of $\mathrm{C}$, with two fruits with symptoms related to Curvularia spicifera and five to Alternaria alternata. All of the samples collected in the Monopoli and Baranello areas showed infection levels of A (Table 6).

Identification of seedborne fungi using morphological criteria and molecular tools. After 14 days of incubation using the blotter test at $22 \pm 2{ }^{\circ} \mathrm{C}$ with a $12 / 12$-h dark/ultraviolet light photoperiod, all of these seeds were examined under a stereomicroscope for the presence of fungal fruiting bodies. The fruiting bodies and fungal structures (i.e., pycnidia, sporodochia, perithecia, conidia) were also analyzed under microscopy to evaluate the shape and size. For each fungal species identified by morphological criteria, there was a parallel molecular identification (sequence analysis and amplification by specific primers). The main fungi isolated from seeds were Stagonosporopsis cucurbitacearum, Albifimbria verrucaria, Paramyrothecium roridum, Stemphylium vesicarium, Alternaria alternata, Curvularia spicifera, $F$. solani, and $F$. oxysporum, whose descriptions are reported in the following subsections.

Stagonosporopsis cucurbitacearum (Fr.) Aveskamp, Gruyter \& Verkley (Aveskamp et al. 2010) [syns. Didymella bryoniae (Fuckel) Rehm]. Pycnidia were observed on squash seeds with diameters ranging from 116 to $131 \mu \mathrm{m}$ (Fig. 3A, B, and C). These spores were cylindrical with rounded ends (4.0 to $8.0 \times 1.6$ to $3.4 \mu \mathrm{m})$ (Fig. 3D). The mycelia of the colonies cultured on PDA were white on the top and black on the bottom, and they produced pycnidia with pycnidiospores after 10 days (Fig. 3E). These morphological traits are consistent with Stagonosporopsis cucurbitacearum.

By sequence analysis, isolates D33, D29, D49, D12, and D83 showed high nucleotide identity with Stagonosporopsis cucurbitacearum (Table 2) and the molecular tools proposed by Brewer et al. (2015) also corroborated the morphological identification (data not shown). Finally, the amplification with the RG-specific primer pair, able to yield a specific fragment of about $450 \mathrm{bp}$, allowed molecular characterization of all analyzed isolates as Stagonosporopsis cucurbitacearum belonging to the RG group II (Fig. 4A) (Somai et al. 2002).

Albifimbria verrucaria (Alb. \& Schwein.) L. Lombard \& Crous (Lombard et al. 2016) [syns. Myrothecium verrucaria (Alb. \& Schwein.) Ditmar]. On squash seeds there was an erumpent crowded cluster of conidiophores that formed a viscus stroma in the form of a cushion. These fruiting bodies are known as sporodochia, and their color was green to dark green, they were surrounded by white cotton mycelia on the seeds (Fig. 3I), and they had a large number of elliptical one-celled conidia with acute ends ( 4.1 to $5.7 \times 1.5$ to $2.2 \mu \mathrm{m}$ ) (Fig. 3J). On PDA, this fungus produced white colonies that became greenish black with time, to form black rings of sporodochia. These morphological criteria attributed this fungus to the species Albifimbria verrucaria, which was confirmed by the sequence analysis for isolates M144, M135, IAV2, and IAV4 (Table 2).

For the molecular identification of Albifimbria verrucaria, specific primers were designed. The primer pair Myroverr F1/R1 was used in PCR reactions in a gradient thermal cycler to determine its maximal annealing temperature, then $60^{\circ} \mathrm{C}$ was applied. These conditions yielded a specific fragment of $553 \mathrm{bp}$ amplicons (Fig. 5A). The minimum concentration of the target DNA that could be detected with this primer was $4 \times 10^{\circ} \mathrm{ng}$ (data not shown).

Paramyrothecium roridum (Tode) L. Lombard \& Crous (Lombard et al. 2016) (syns. Myrothecium roridum Tode). In other cases, the sporodochia were black to black green and globular, with a rounded
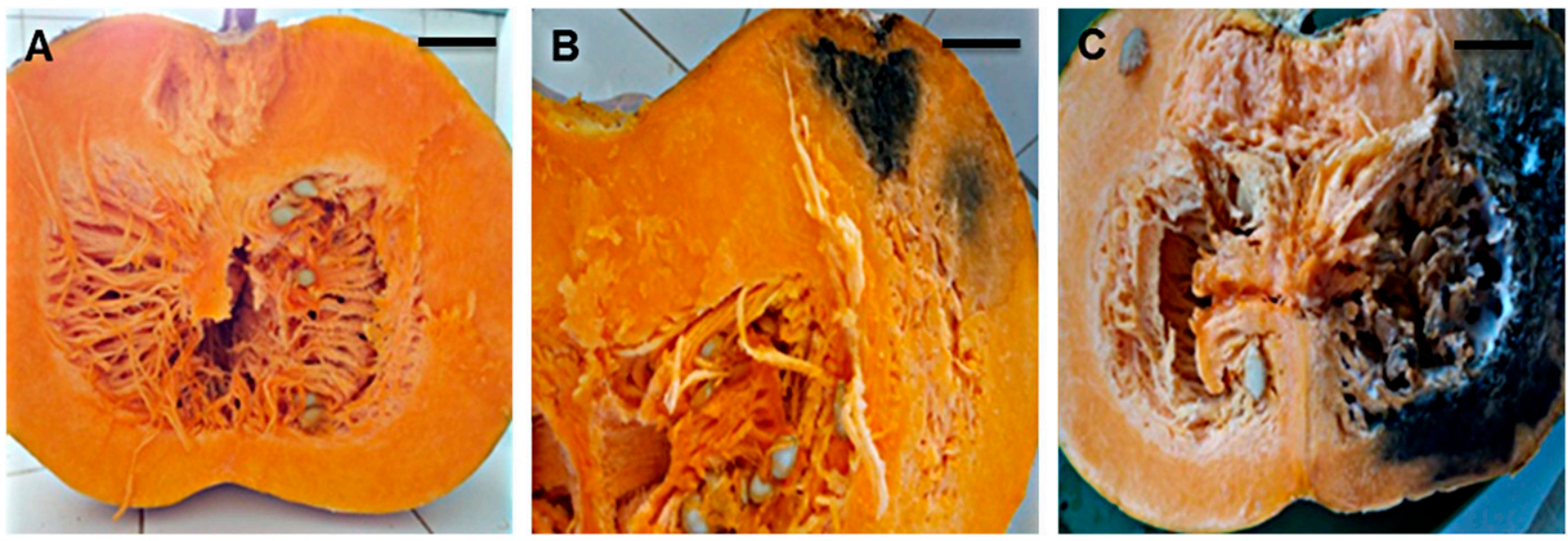

Fig. 2. Evaluation of symptoms on squash fruit collected from growers. A, Asymptomatic fruit. B, Infected fruit showing symptoms of rot on squash skin without reaching the seed cavity. C, Infected fruit showing symptoms of rot that has reached the seed cavity. Scale bars $=5 \mathrm{~cm}$. 
contour and without obvious mycelia (Fig. 3K). Conidia taken from these sporodochia were one-celled and cylindrical, with rounded ends (Fig. 3L). On PDA, this fungus formed white colonies that with time produced successive greenish-black and black rings of sporodochia filled with the cylindrical conidia (5.0 to $7.4 \times 1.2$ to $2.6 \mu \mathrm{m}$ ). These morphological features indicated that this fungus corresponded to
Paramyrothecium roridum, which was confirmed by the sequence analysis for isolates M123, M138, M141, IPR2, and IPR9 (Table 2).

For the molecular identification of Paramyrothecium roridum, specific primers were again designed. The primer pair Myroror F1/R1 was used in PCR reactions in a gradient thermal cycler to determine its maximal annealing temperature, then $58^{\circ} \mathrm{C}$ was applied. These

Table 2. Codes assigned to the isolates of each fungal species from Tunisia (TN) and Italy (IT) that were used during the DNA extraction and PCR analyses of the internal transcribed spacer (ITS), translation elongation factor (EF1 $\alpha$ ), histone H3 (HIS), and $\beta$-tubulin (TUB) sequences

\begin{tabular}{|c|c|c|c|c|c|c|c|c|c|c|}
\hline \multirow[b]{3}{*}{ Fungal species } & \multirow[b]{3}{*}{ Isolate } & \multirow[b]{3}{*}{ Location } & \multirow[b]{3}{*}{ Source } & \multirow[b]{3}{*}{ Host species } & \multicolumn{2}{|c|}{ Identification method ${ }^{\mathrm{a}}$} & & & & \\
\hline & & & & & \multirow[b]{2}{*}{ Sequencing } & \multirow{2}{*}{$\begin{array}{c}\text { Species- } \\
\text { specific } \\
\text { PCR }\end{array}$} & \multicolumn{4}{|c|}{ GenBank accession number } \\
\hline & & & & & & & ITS & EF1 $\alpha$ & HIS & TUB \\
\hline \multirow[t]{29}{*}{$\begin{array}{c}\text { Stagonosporopsis } \\
\text { cucurbitacearum }\end{array}$} & D33 & Sidi Hmada, TN & Seed & $\begin{array}{r}\text { Cucurbita } \\
\text { maxima }\end{array}$ & + & + & MF401569 & - & - & MK497768 \\
\hline & D35 & Sidi Hmada, TN & Seed & C. maxima & & + & & & & \\
\hline & D43 & Sidi Hmada, TN & Seed & C. maxima & & + & & & & \\
\hline & D45 & Sidi Hmada, TN & Seed & C. maxima & & + & & & & \\
\hline & D40 & Sidi Hmada, TN & Seed & C. maxima & & + & & & & \\
\hline & D36 & Sidi Hmada, TN & Seed & C. maxima & & + & & & & \\
\hline & D3 & Sbeitla, TN & Seed & C. maxima & & + & & & & \\
\hline & D23 & Sidi Hmada, TN & Seed & C. maxima & & + & & & & \\
\hline & $\mathrm{D} 24$ & Sidi Hmada, TN & Seed & C. maxima & & + & & & & \\
\hline & D29 & Sidi Hmada, TN & Seed & C. maxima & + & + & MK497779 & - & - & MK497766 \\
\hline & $\mathrm{D} 21$ & Sidi Hmada, TN & Seed & C. maxima & & + & & & & \\
\hline & D5 & Sbeïtla, TN & Seed & C. maxima & & + & & & & \\
\hline & D42 & Sidi Hmada, TN & Seed & C. maxima & & + & & & & \\
\hline & D49 & Sidi Hmada, TN & Seed & C. maxima & + & + & MF401570 & - & MK497771 & MK497767 \\
\hline & D48 & Sidi Hmada, TN & Seed & C. maxima & & + & & & & \\
\hline & D45 & Sidi Hmada, TN & Seed & C. maxima & & + & & & & \\
\hline & D39 & Sidi Hmada, TN & Seed & C. maxima & & + & & & & \\
\hline & $\mathrm{D} 2$ & Sbeïtla, TN & Seed & C. maxima & & + & & & & \\
\hline & D3 & Sbeïtla, TN & Seed & C. maxima & & + & & & & \\
\hline & D5 & Sbeïtla, TN & Seed & C. maxima & & + & & & & \\
\hline & D10 & Sbeïtla, TN & Seed & C. maxima & & + & & & & \\
\hline & $\mathrm{D} 12$ & Sidi Hmada, TN & Seed & C. maxima & + & + & MF401568 & - & - & - \\
\hline & D27 & Sidi Hmada, TN & Seed & C. maxima & & + & & & & \\
\hline & D62 & Sidi Hmada, TN & Seed & C. maxima & & + & & & & \\
\hline & D69 & Sidi Hmada, TN & Seed & C. maxima & & + & & & & \\
\hline & D83 & Sidi Hmada, TN & Seed & C. maxima & + & + & MF401571 & - & - & - \\
\hline & DBF1 & Osimo, IT & Fruit & $\begin{array}{l}\text { Curcubita } \\
\text { moschata }\end{array}$ & & + & & & & \\
\hline & DBF2 & Osimo, IT & Fruit & C. moschata & & + & & & & \\
\hline & DBF3 & Osimo, IT & Fruit & C. moschata & & + & & & & \\
\hline Phoma sp. & Ph39 & Sidi Hmada, TN & Seed & C. maxima & + & & MF401572 & - & - & - \\
\hline \multirow[t]{17}{*}{ Alternaria alternata } & A38 & Sahline, TN & Seed & C. maxima & + & + & MK497774 & MK497789 & MK497770 & - \\
\hline & A15 & $\begin{array}{l}\text { Kalâat El- } \\
\text { Andalous, TN }\end{array}$ & Seed & C. maxima & + & + & MK497773 & MK497788 & MK497769 & - \\
\hline & A58 & $\begin{array}{l}\text { Kalâat El- } \\
\text { Andalous, TN }\end{array}$ & Seed & C. maxima & & + & & & & \\
\hline & A17 & $\begin{array}{l}\text { Kalâat El- } \\
\text { Andalous, TN }\end{array}$ & Seed & C. maxima & & + & & & & \\
\hline & A5 & $\begin{array}{l}\text { Kalâat El- } \\
\text { Andalous, TN }\end{array}$ & Seed & C. maxima & & + & & & & \\
\hline & A59 & Sidi Hmada, TN & Seed & C. maxima & & + & & & & \\
\hline & IA 1 & Recanati, IT & Seed & C. moschata & + & + & MK497775 & - & - & - \\
\hline & IA 2 & Recanati, IT & Fruit & C. moschata & & + & & & & \\
\hline & IA3 & Osimo, IT & Seed & C. moschata & + & + & MK497776 & - & - & - \\
\hline & IA 4 & Osimo, IT & Seed & C. moschata & & + & & & & \\
\hline & IA5 & Osimo, IT & Fruit & C. moschata & & + & & & & \\
\hline & IA6 & Osimo, IT & Seed & C. moschata & & + & & & & \\
\hline & IA7 & Monopoli, IT & Seed & C. moschata & & + & & & & \\
\hline & IA8 & Monopoli, IT & Seed & C. moschata & & + & & & & \\
\hline & IA9 & Castelfidardo, IT & Seed & C. maxima & & + & & & & \\
\hline & IA10 & Castelfidardo, IT & Seed & C. maxima & & + & & & & \\
\hline & & & & & & & & & \multicolumn{2}{|c|}{ (Continued on next page) } \\
\hline
\end{tabular}

\footnotetext{
${ }^{a}$ A plus sign indicates a positive result with the identification method.
}

${ }^{\mathrm{b}}$ A dash indicates that the sequence is not available. 
conditions yielded a specific fragment of $562 \mathrm{bp}$ amplicons (Fig. 5B). The minimum concentration of target DNA that could be detected with this primer was $4 \times 10^{\circ} \mathrm{ng}$ (data not shown).

Stemphylium vesicarium (Wallr.) E.G. Simmons (Simmons, 1969) [syns. Pleospora herbarum (Pers.) Rabenh.]. Small black fruiting bodies (perithecia) that were flask shaped or globose appeared on the squash seed samples (Fig. 3O), with a size of 147 to $282 \times 131$ to $243 \mu \mathrm{m}$. The crushed perithecium discharged several bitunicate clavate asci that measured 50 to $116 \times 8.4$ to $18.3 \mu \mathrm{m}$ (Fig. 3P).
These contained eight ellipsoidal monoseriate to biseriate ascospores that were rounded at the ends ( 14.7 to $20.0 \times 6.1$ to $9.5 \mu \mathrm{m}$ ), with four to six transverse and one to three longitudinal septa (Fig. 3Q). After 4 to 6 days on PDA, this fungus produced one muriform conidium per conidiophore (anamorph). The length of the conidia was 8.4 to $18.7 \times$ 6.0 to $11.1 \mu \mathrm{m}$, with three transverse and one to three longitudinal septa. After 10 to 15 days on PDA, the fungus started to differentiate perithecia (teleomorph). The isolates that showed these morphological features were closely related to the fungal species

Table 2. (Continued from previous page)

\begin{tabular}{|c|c|c|c|c|c|c|c|c|c|c|}
\hline \multirow[b]{3}{*}{ Fungal species } & \multirow[b]{3}{*}{ Isolate } & \multirow[b]{3}{*}{ Location } & \multirow[b]{3}{*}{ Source } & \multirow[b]{3}{*}{ Host species } & \multicolumn{2}{|c|}{ Identification method $^{\text {a }}$} & & & & \\
\hline & & & & & \multirow[b]{2}{*}{ Sequencing } & \multirow{2}{*}{$\begin{array}{l}\text { Species- } \\
\text { specific } \\
\text { PCR }\end{array}$} & \multicolumn{4}{|c|}{ GenBank accession numberb } \\
\hline & & & & & & & ITS & EF1 $\alpha$ & HIS & TUB \\
\hline \multirow{13}{*}{$\begin{array}{c}\text { Albifimbria } \\
\text { verrucaria }\end{array}$} & M140 & Sidi Hmada, TN & Seed & C. maxima & & + & & & & \\
\hline & M149 & Sidi Hmada, TN & Seed & C. maxima & & + & & & & \\
\hline & M148 & Sidi Hmada, TN & Seed & C. maxima & & + & & & & \\
\hline & M144 & Sidi Hmada, TN & Seed & C. maxima & + & + & MK497782 & - & - & MK497761 \\
\hline & M146 & Sidi Hmada, TN & Seed & C. maxima & & + & & & & \\
\hline & M155 & Sidi Hmada, TN & Seed & C. maxima & & + & & & & \\
\hline & M135 & Sidi Hmada, TN & Seed & C. maxima & + & + & MK497783 & - & - & MK497762 \\
\hline & IAV1 & Osimo, IT & Seed & C. moschata & & + & & & & \\
\hline & IAV2 & Osimo, IT & Seed & C. moschata & + & + & MK497785 & - & - & MK497764 \\
\hline & IAV3 & Osimo, IT & Seed & C. moschata & & + & & & & \\
\hline & IAV4 & Osimo, IT & Seed & C. moschata & + & + & MK497784 & - & - & MK497763 \\
\hline & M73 & Sidi Hmada TN & Seed & C. maxima & & + & & & & \\
\hline & M78 & Sidi Hmada, TN & Seed & C. maxima & & + & & & & \\
\hline \multirow{13}{*}{$\begin{array}{l}\text { Paramyrothecium } \\
\text { roridum }\end{array}$} & M123 & Sidi Hmada, TN & Seed & C. maxima & + & + & MF401575 & - & - & MK497759 \\
\hline & M138 & Sidi Hmada, TN & Seed & C. maxima & + & + & MF401576 & - & - & - \\
\hline & M167 & Sidi Hmada, TN & Seed & C. maxima & & + & & & & \\
\hline & M141 & Sidi Hmada, TN & Seed & C. maxima & + & + & MK497786 & - & - & MK497765 \\
\hline & IPR1 & Baranello, IT & Seed & C. moschata & & + & & & & \\
\hline & IPR2 & Baranello, IT & Seed & C. moschata & + & + & - & - & - & MK497760 \\
\hline & IPR3 & Baranello, IT & Seed & C. moschata & & + & & & & \\
\hline & IPR4 & Recanati, IT & Seed & C. moschata & & + & & & & \\
\hline & IPR5 & Recanati, IT & Seed & C. moschata & & + & & & & \\
\hline & IPR6 & Recanati, IT & Seed & C. moschata & & + & & & & \\
\hline & IPR7 & Recanati, IT & Seed & C. moschata & & + & & & & \\
\hline & IPR8 & Recanati, IT & Seed & C. moschata & & + & & & & \\
\hline & IPR9 & Recanati, IT & Seed & C. moschata & + & + & MK497780 & - & - & - \\
\hline \multirow{3}{*}{$\begin{array}{l}\text { Fusarium } \\
\text { oxysporum }\end{array}$} & F59 & Sidi Hmada, TN & Seed & C. maxima & & + & & & & \\
\hline & F16 & Sbeïtla, TN & Seed & C. maxima & & + & & & & \\
\hline & F19 & $\begin{array}{l}\text { Kalâat El- } \\
\text { Andalous, TN }\end{array}$ & Seed & C. maxima & & + & & & & \\
\hline \multirow[t]{4}{*}{ F. solani } & F82 & Sbeïtla, TN & Seed & C. maxima & & + & & & & \\
\hline & F30 & Sidi Hmada, TN & Seed & C. maxima & & + & & & & \\
\hline & F174 & Sbeitla, TN & Seed & C. maxima & + & + & MF401578 & MK497790 & MK497772 & - \\
\hline & F142 & Sidi Hmada, TN & Seed & C. maxima & & + & & & & \\
\hline \multirow[t]{7}{*}{ Curvularia spicifera } & B172 & Sbeïtla, TN & Seed & C. maxima & & + & & & & \\
\hline & $\mathrm{B} 170$ & Sidi Hmada, TN & Seed & C. maxima & + & + & MF401577 & - & - & - \\
\hline & IB41 & $\begin{array}{l}\text { Castelfidardo, } \\
\text { IT }\end{array}$ & Seed & C. maxima & + & + & MK497777 & & & \\
\hline & IB4 & $\begin{array}{l}\text { Castelfidardo, } \\
\text { IT }\end{array}$ & Fruit & C. maxima & & + & & & & \\
\hline & IB1 & $\begin{array}{l}\text { Castelfidardo, } \\
\text { IT }\end{array}$ & Seed & C. maxima & + & + & MK497778 & - & - & - \\
\hline & IB2 & Recanati, IT & Seed & C. moschata & & + & & & & \\
\hline & IB3 & Recanati, IT & Seed & C. moschata & & + & & & & \\
\hline \multirow[t]{5}{*}{$\begin{array}{c}\text { Stemphylium } \\
\text { vesicarium }\end{array}$} & P164 & $\begin{array}{l}\text { Kalâat El- } \\
\text { Andalous, TN }\end{array}$ & Seed & C. maxima & + & + & MF401574 & MK497787 & - & - \\
\hline & P66 & $\begin{array}{l}\text { Kalâat El- } \\
\text { Andalous, TN }\end{array}$ & Seed & C. maxima & + & + & MF401573 & MK497791 & - & - \\
\hline & IP41 & Baranello, IT & Seed & C. moschata & & + & & & & \\
\hline & IP4 & Osimo, IT & Seed & C. moschata & + & + & MK497781 & - & - & - \\
\hline & IP5 & Osimo, IT & Seed & C. moschata & & + & & & & \\
\hline
\end{tabular}


Stemphylium vesicarium, which was confirmed by the sequence analysis of isolates P164, P66, and IP4 (Table 2).

For the molecular identification of Stemphylium vesicarium, the primer pairs Pleo F/R (Fig. 5C) and Pleo F1/R1 (Fig. 5D) were designed, and these successfully amplified the target DNA from the five isolates of Stemphylium vesicarium. The annealing temperature was $60^{\circ} \mathrm{C}$, and under these conditions a specific fragment of $547 \mathrm{bp}$ was yielded. The detection limit for these primers was approximately $4 \times 10^{-1} \mathrm{ng}$ of fungal DNA input (data not shown).

Alternaria alternata (Fr.) Keissl. (1912). Black conidia were observed in long chains on all of the seed samples, except for sample Bj52 (Fig. 3F and G). Microscopic examination showed conidia that were highly variable in shape $(5.0$ to $17.0 \times 4.0$ to $8.5 \mu \mathrm{m})$, with both transverse and longitudinal septa (Fig. 3H). The conidial beaks were also highly variability in shape, with lengths of 1.7 to $14.0 \mu \mathrm{m}$. On PDA cultures, the mycelia of this fungus were at first gray, but then became nearly black when sporulation was abundant. The morphological features of this fungus corresponded to the fungal species Alternaria alternata, which was confirmed by the sequence analysis of isolates A38, A15, IA1, and IA3 (Table 2).

For the molecular identification of Alternaria alternata, the set of primers AAF2/AAR3 (Konstantinova et al. 2002) yielded a specific fragment of about $350 \mathrm{bp}$ (Fig. 4B).

Curvularia spicifera (Bainier) Boedijn (Boedijn, 1933) [syns. Bipolaris spicifera (Bainier) Subram.]. Other conidia were found in groups on squash seed samples (Fig. 3M). Microscopic examination

Table 3. Nucleotide sequence primers already published for the detection of Stagonosporopsis cucurbitacearum, Alternaria alternata, Curvularia spicifera, Fusarium oxysporum, and F. solani

\begin{tabular}{|c|c|c|c|}
\hline Fungal species & Primer pair ${ }^{\mathbf{a}}$ & Sequence $\left(5^{\prime}\right.$ to $\left.3^{\prime}\right)$ & Reference \\
\hline \multirow[t]{4}{*}{ Stagonosporopsis cucurbitacearum } & RGI F & TGTCGTTGAC ATCATTCCAGC & $\begin{array}{l}\text { Babu et al. (2015) and } \\
\text { Somai et al. (2002) }\end{array}$ \\
\hline & RGI R & ACCACTCTGCTTAGTATCTGC & \\
\hline & RGII $F$ & GCTAAGCCTT AATCTAGCTGC & \\
\hline & RGII R & GAGAGTAAGCTAACCTAAAGG & \\
\hline \multirow{6}{*}{$\begin{array}{l}\text { Stagonosporopsis spp. (S. cucurbitacearum, } \\
\text { S. citrulli, S. caricae) }\end{array}$} & $\mathrm{Db} 01 \mathrm{~F}$ & CACGCCAGCAAATCTCACTA & Brewer et al. (2015) \\
\hline & Db01R & CGGTCCGGTCAACCTACTAC & \\
\hline & $\mathrm{Db} 05 \mathrm{~F}$ & TATGACGTTGGGCAAGTGAG & \\
\hline & Db05R & TTTGCTGGGATGGTGTTGTA & \\
\hline & $\mathrm{Db} 06 \mathrm{~F}$ & GGTGACATCTTGCGTGAATG & \\
\hline & Db06R & TGGTTGTTTGGTTGTTTGGA & \\
\hline \multirow[t]{2}{*}{ Alternaria alternata } & AAF2 & TGCAATCAGCGTCAGTAACAAAT & Konstantinova et al. (2002) \\
\hline & AAR3 & ATGGATGCTAGACCTTTGCTGAT & \\
\hline \multirow[t]{2}{*}{ Curvularia spicifera } & Bipol-1F & CAGTTGCAATCAGCGTCAGT & Ünal et al. (2011) \\
\hline & Bipol-1R & AAGACAAAAACGCCCAACAC & \\
\hline \multirow[t]{2}{*}{ Fusarium oxysporum } & FC-1 & CATACCACTTGTTGCCTC & Zhang et al. (2012) \\
\hline & FC-2 & ATTAACGCGAGTCCCACC & \\
\hline \multirow[t]{2}{*}{ F. solani } & TEF-Fs4 F & ATCGGCCACGTCGACTCT & Arif et al. (2012) \\
\hline & TEF-Fs4 R & GGCGTCTGTTGATTGTTAGC & \\
\hline \multirow[t]{2}{*}{ F. solani f. sp. cucurbitae race 1} & Fsc1EF1 & GCTAACAATCATCTACAGAC & Mehl and Epstein (2007) \\
\hline & Fsc1-EF-2 & GACGGATGAGAGAGCAAC & \\
\hline \multirow[t]{2}{*}{ F. solani f. sp. cucurbitae race 2} & Fsc2-EF1 & GTTGGTGACATATCTCCC & \\
\hline & Fsc2-EF3 & GAGTGAGAGACATGACGG & \\
\hline
\end{tabular}

${ }^{\mathrm{a}} \mathrm{F}=$ forward and $\mathrm{R}=$ reverse.

Table 4. Characteristics of the genus-specific and species-specific primers designed for Albifimbria verrucaria, Paramyrothecium roridum, and Stemphylium vesicarium

\begin{tabular}{|c|c|c|c|c|c|}
\hline Target sequence species & Primer name $^{\mathbf{a}}$ & Sequence $\left(5^{\prime}\right.$ to $\left.3^{\prime}\right)$ & $\operatorname{Tm}\left({ }^{\circ} \mathbf{C}\right)^{\mathbf{b}}$ & Bases $(n)$ & GC content $(\%)$ \\
\hline \multirow[t]{2}{*}{ Albifimbria verrucaria } & Myroverr F1 & 5'-TGTGAACCTTACCATATTGTTGC-3' & 62.4 & 23 & 39.1 \\
\hline & Myroverr R1 & 5'-CGTTCCAACTGCGAGGTTGT-3' & 67.4 & 20 & 55.0 \\
\hline \multirow[t]{2}{*}{ Paramyrothecium roridum } & Myroror F1 & 5'-CССТTTGTGAACCTTACCTAT-3' & 58.5 & 21 & 42.8 \\
\hline & Myroror R1 & 5'-AGCTCCAATGCGAGTTGTG-3' & 64.1 & 19 & 52.6 \\
\hline \multirow[t]{4}{*}{ Stemphylium vesicarium } & Pleo F & 5'-TACACAATATGAAAGCGGGTTG-3' & 63.7 & 22 & 40.9 \\
\hline & Pleo R & 5'-AAGGCTGATTCAAAGTGCAAG-3' & 63.2 & 21 & 42.8 \\
\hline & Pleo F1 & 5'-ATTCACCCATGTCTTTTGCG-3' & 64.7 & 20 & 45.0 \\
\hline & Pleo R1 & 5'-AAATGTGGTCTTGATGGATGC-3' & 63.7 & 21 & 42.8 \\
\hline
\end{tabular}

${ }^{\mathrm{a}} \mathrm{F}=$ forward and $\mathrm{R}=$ reverse.

${ }^{\mathrm{b}} \mathrm{Tm}=$ melting temperature.

Table 5. Cycling conditions for the newly designed primers

\begin{tabular}{|c|c|c|c|c|c|}
\hline \multirow[b]{2}{*}{ Target sequence species } & \multicolumn{2}{|c|}{ Designed primer pair } & \multicolumn{3}{|c|}{ Validated PCR program } \\
\hline & Forward & Reverse & Initial denaturation & Denaturation: 25 cycles & $\overline{\text { Annealing }}$ \\
\hline Albifimbria verrucaria & Myroverr F1 & Myroverr R1 & $95^{\circ} \mathrm{C}, 2 \mathrm{~min}$ & $95^{\circ} \mathrm{C}$ for $30 \mathrm{~s}, 60^{\circ} \mathrm{C}$ for $30 \mathrm{~s}, 72^{\circ} \mathrm{C}$ for $30 \mathrm{~s}$ & $72^{\circ} \mathrm{C}, 5 \mathrm{~min}$ \\
\hline Paramyrothecium roridum & Myroror F1 & Myroror R1 & $95^{\circ} \mathrm{C}, 2 \mathrm{~min}$ & $95^{\circ} \mathrm{C}$ for $30 \mathrm{~s}, 58^{\circ} \mathrm{C}$ for $30 \mathrm{~s}, 72^{\circ} \mathrm{C}$ for $30 \mathrm{~s}$ & $72^{\circ} \mathrm{C}, 5 \mathrm{~min}$ \\
\hline Stemphylium vesicarium & $\begin{array}{l}\text { Pleo F } \\
\text { Pleo F1 }\end{array}$ & $\begin{array}{l}\text { Pleo R } \\
\text { Pleo R1 }\end{array}$ & $95^{\circ} \mathrm{C}, 2 \mathrm{~min}$ & $95^{\circ} \mathrm{C}$ for $30 \mathrm{~s}, 60^{\circ} \mathrm{C}$ for $30 \mathrm{~s}, 72^{\circ} \mathrm{C}$ for $30 \mathrm{~s}$ & $72^{\circ} \mathrm{C}, 5 \mathrm{~min}$ \\
\hline
\end{tabular}


showed straight conidia with rounded ends, with three distosepta, which measured 12.0 to $23.4 \times 5.1$ to $8.0 \mu \mathrm{m}$ (Fig. $3 \mathrm{~N}$ ). These morphological features belong to the fungal species Curvularia spicifera, which was confirmed by the sequence analysis of isolates B170, IB41, and IB1 (Table 2).

For the molecular identification of Curvularia spicifera, the primer pair Bipol-1F/Bipol-1R amplified a specific fragment of $200 \mathrm{bp}$ amplicons for the two isolates tested (Fig. 4C) (Ünal et al. 2011).

F. solani (Mart. 1842) [syns. Neocosmospora solani (Mart.) L. Lombard \& Crous (Lombard et al. 2015)]. A fungus characterized by the presence of water droplets was found on seed samples (Fig. 3R). Microscopic examination showed long phialides (Fig. 3S), unicellular and bicellular oval microconidia (size of 6.0 to $14.6 \times 2.0$ to $4.1 \mu \mathrm{m}$ ), and cylindrical and slightly curved macroconidia, three to five septate (mean size of 16.6 to $33.4 \times 3.0$ to $5.2 \mu \mathrm{m}$ ) (Fig. 3T). On PDA culture, the fungus produced white to cream-colored mycelia. These morphological features indicated that this belonged to the fungal species $F$. solani, which was confirmed by the sequence analysis of isolate F174 (Table 2).

For the molecular identification, the amplification carried out with the specific primers TEF-Fs4f/TEF-Fs4r (Arif et al. 2012) (Fig. 4D) yielded a specific fragment of about $650 \mathrm{bp}$ amplicons. We did not have any amplification with the primer pairs Fsc1EF1/Fsc1-EF-2 and Fsc2-EF1/Fsc2-EF3.

F. oxysporum Schltdl. 1824. Microscopic examination showed unicellular and bicellular microconidia produced on short monophilides. The macroconidia were generally three to five septate. There were chlamydospores in the mycelial cultures, which were round unicellular and bicellular and surrounded by a thick cell wall. The fungus developed on PDA culture had white mycelia that became salmon in color, with a tendency to purple. These morphological features indicated that it belonged to the fungal species $F$. oxysporum.

For the molecular identification, the amplification carried out with the specific primers Fc-1/Fc-2 (Zhang et al. 2012) (Fig. 4E) yielded a specific fragment of approximately $400 \mathrm{bp}$.

Frequency of seedborne fungi. The seedborne fungi isolated from the seed samples collected in Tunisia were Alternaria alternata (25.1\%), followed by Stagonosporopsis cucurbitacearum (24.6\%), F. solani (16.6\%), R. stolonifer (13.3\%), F. fujikuroi (7.8\%), Albifimbria verrucaria $(3.3 \%)$, and Stemphylium vesicarium (2.3\%). Alternaria alternata was detected in all of the localities surveyed and in most of the symptomatic fruits (T8, T34, T47, T71, T35, T63, T45, and T69 in Table 6), with an infection level of 6 to 50\%. Moreover, Alternaria alternata was also detected in 22 asymptomatic fruits collected from these five localities in Tunisia, with incidence ratings from 1 to $38 \%$. Stagonosporopsis cucurbitacearum was detected in three Tunisia localities (Sidi Hmada, Sbeitla, and Utique) from three symptomatic fruits (T7, T8, and T9) collected from the Sidi Hmada area (Table 6). The seed samples extracted from these fruits were highly infected by Stagonosporopsis cucurbitacearum, with infection rates from 20 to $60 \%$. Furthermore, Stagonosporopsis cucurbitacearum was also identified in the seed samples from 12 asymptomatic fruits collected from these three localities, with infection rates from 1 to $44 \%$. F. solani was detected in 17 seed samples collected from all five localities in Tunisia ( $46 \%$ of samples). F. solani was isolated from one symptomatic fruit (T52 in Table 6), with an infection rate of $7 \%$. Moreover, $F$. solani was isolated and identified in 13 asymptomatic fruits, with infection rates from 1 to $60 \%$. Albifimbria verrucaria and Paramyrothecium roridum were isolated from four seed samples obtained from asymptomatic fruits collected from the Sidi Hmada area. Seed sample T18 in Table 7 was highly infected by Albifimbria verrucaria $(15.5 \%)$ and Paramyrothecium roridum (5.0\%). Stemphylium vesicarium was isolated from 18 seed samples (48.6\% of samples), with infection rates from 1 to 13\%. Curvularia spicifera was isolated from 12 seed samples (32.4\% of samples) collected from all five localities, with incidence rates of 1 to $7 \%$.

In the seed samples from Italy, Alternaria alternata was also the most frequent $(40.0 \%)$, followed by $F$. fujikuroi $(20.8 \%)$,
Stemphylium vesicarium (3.0\%), and Curvularia spicifera $(2.1 \%)$ (Table 7). Alternaria alternata was detected for all of the localities included. This pathogen was isolated from all of the symptomatic fruit samples and also from the seeds extracted from these fruits, with infection rates from 1 to $70 \%$. Moreover, Alternaria alternata was identified in eight asymptomatic fruits, with infection rates from 1 to $37 \%$. Stemphylium vesicarium was detected in 12 of the seed samples collected (41.3\% of samples), with incidence rates from 1 to $9 \%$. The seeds obtained from three symptomatic fruit samples with an infection level of C were infected by Curvularia spicifera (I2, I5, and I31 in Table 6), with infection rates from 11 to $85 \%$. Moreover, another symptomatic fruit sample with an infection level of B was infected with Curvularia spicifera (I29 in Table 6), with an infection rate of $2 \%$. Curvularia spicifera was also identified in the seed samples of two asymptomatic fruits (I23 and I37 in Table 6), with an infection rate of $1 \%$.

\section{Discussion}

In this study, a survey was carried out to assess the phytosanitary status of squash seeds collected from fruit samples produced in Tunisia and Italy. The survey allowed us to isolate and identify several fungi in squash seeds, including Stagonosporopsis cucurbitacearum, Alternaria alternata, F. solani, Albifimbria verrucaria, Paramyrothecium roridum, Stemphylium vesicarium, and Curvularia spicifera.

We observed a correlation between the symptoms caused on these fruits collected in Tunisia and Italy and the fungal species isolated from seeds of these fruits. Our data show that Alternaria alternata and Stagonosporopsis cucurbitacearum were detected and isolated from fruit lesions in both countries. Alternaria alternata is a pathogen of cucurbits, where it can cause severe crop losses (Vakalounakis 1990). Stagonosporopsis cucurbitacearum has a worldwide distribution and it can infect at least 12 genera and 23 species of Cucurbitaceae (Rennberger and Keinath 2018; Stewart et al. 2015). Stagonosporopsis cucurbitacearum was reported in Italy in 1885 on Cucumis melo (Corlett 1981) and in 2019 on Cucurbita moschata (Moumni et al. 2019). In Tunisia, Stagonosporopsis cucurbitacearum was detected only on watermelon (Citrullus lanatus) in 2007 (Boughalleb et al. 2007). To our knowledge, our work represents the first report of Stagonosporopsis cucurbitacearum as a pathogen of squash seed in Tunisia.

The pathogenic fungi Alternaria alternata, Stagonosporopsis cucurbitacearum, and Curvularia spicifera were present in high percentages for seeds obtained from symptomatic fruits. Therefore, seeds can be infected indirectly through the fruit, when a lesion extends to the seed cavity, or during the process of seed extraction, when the seeds are mixed with the inoculum present on the external part of the fruit, as demonstrated by Mehl and Epstein (2007).

Seedborne fungi were also detected in the asymptomatic fruits. Stagonosporopsis cucurbitacearum was detected in 12 asymptomatic fruits collected from the Tunisia areas. Similar data were obtained for Alternaria alternata, which was present in all of the 30 asymptomatic fruits collected in Tunisia and Italy. Furthermore, $F$. solani was isolated from 13 seed samples extracted from asymptomatic fruits. As shown for Stagonosporopsis sp., Fusarium sp., and Alternaria sp., even if the fruit does not show any symptoms, the seeds inside the fruit can be infected (El-Meleigi 1991; Keinath 2011; Petkar and Ji 2017). This finding shows that there are other mechanisms of pathogen penetration. Fusarium wilt of watermelon ( $F$. oxysporum f. sp. niveum) can infect watermelon seeds by direct invasion through vascular bundles or indirect invasion through the pistil, which can lead to infestation of seeds in asymptomatic fruit (Petkar and Ji 2017). Halfon-Meiri and Rilsky (1983) indicated that conidia of Alternaria alternata can germinate on stigmas of pepper flowers, ingress the ovary through the style in the form of hyphae, and establish in pepper seeds. Similarly, de Neergaard (1989) showed that Stagonosporopsis sp. can infect seeds of Cucurbitaceae via the stigmas. Moreover, the majority of growers in Tunisia and Italy extract the seeds from the fruit, and the presence of seeds contaminated within asymptomatic fruits might contribute to the 
Table 6. Incidence of different seedborne fungi detected on all of the squash samples using blotter tests

\begin{tabular}{|c|c|c|c|c|c|c|c|c|c|}
\hline \multirow[b]{2}{*}{ Country } & \multirow[b]{2}{*}{ Sample code } & \multirow[b]{2}{*}{ Region $^{\mathbf{a}}$} & \multirow{2}{*}{$\begin{array}{l}\text { Fungal species } \\
\text { on fruit }^{\mathbf{b}}\end{array}$} & \multirow{2}{*}{$\begin{array}{c}\text { Level } \\
\text { of symptoms }\end{array}$} & \multicolumn{5}{|c|}{ Incidence of fungal species $(\%)^{d}$} \\
\hline & & & & & Total $^{\mathrm{e}}$ & $A a$ & As & $A b$ & $C s$ \\
\hline \multirow[t]{37}{*}{ Tunisia } & $\mathrm{T} 4$ & $\mathrm{SH}$ & - & A & $46.5 \pm 2.9$ & $19.5 \pm 3.3$ & 0.0 & 0.0 & 0.0 \\
\hline & $\mathrm{T} 7$ & $\mathrm{SH}$ & Sc & B & $73.5 \pm 4.3$ & $2.5 \pm 1.4$ & 0.0 & 0.0 & 0.0 \\
\hline & $\mathrm{T} 8$ & $\mathrm{SH}$ & $A a / S c$ & $\mathrm{C}$ & $25.0 \pm 3.0$ & $6.0 \pm 2.5$ & 0.0 & 0.0 & 0.0 \\
\hline & $\mathrm{T} 9$ & $\mathrm{SH}$ & Sc & $\mathrm{C}$ & $64.0 \pm 7.2$ & $0.5 \pm 0.5$ & 0.0 & 0.0 & 0.0 \\
\hline & $\mathrm{T} 13$ & $\mathrm{SH}$ & - & A & $54.5 \pm 6.1$ & $17.0 \pm 4.5$ & 0.0 & 0.0 & 0.0 \\
\hline & $\mathrm{T} 14$ & $\mathrm{SH}$ & - & A & $75.0 \pm 5.9$ & $18.0 \pm 4.0$ & $4.0 \pm 2.5$ & $2.0 \pm 1.6$ & $3.5 \pm 1.3$ \\
\hline & $\mathrm{T} 18$ & $\mathrm{SH}$ & - & A & $57.0 \pm 4.7$ & $16.0 \pm 4.7$ & $2.0 \pm 2.0$ & $1.5 \pm 1.5$ & $2.0 \pm 2.0$ \\
\hline & $\mathrm{T} 22$ & $\mathrm{SH}$ & - & A & $49.0 \pm 5.7$ & $11.0 \pm 4.1$ & 0.0 & 0.0 & 0.0 \\
\hline & T34 & KA & $A a$ & B & $72.0 \pm 6.3$ & $28.0 \pm 5.7$ & 0.0 & $1.0 \pm 0.7$ & 0.0 \\
\hline & $\mathrm{T} 47$ & KA & $A a$ & $\mathrm{~B}$ & $73.0 \pm 4.4$ & $35.0 \pm 3.3$ & 0.0 & $1.5 \pm 0.8$ & $1.0 \pm 0.7$ \\
\hline & $\mathrm{T} 52$ & KA & Fs & B & $14.0 \pm 2.9$ & 0.0 & 0.0 & 0.0 & 0.0 \\
\hline & $\mathrm{T} 71$ & KA & $A a$ & B & $62.0 \pm 4.9$ & $28.5 \pm 4.1$ & 0.0 & $6.0 \pm 1.7$ & 0.0 \\
\hline & T35 & KA & $A a$ & $\mathrm{~B}$ & $77.0 \pm 6.7$ & $49.5 \pm 5.2$ & 0.0 & 0.0 & 0.0 \\
\hline & $\mathrm{T} 63$ & KA & $A a$ & B & $21.5 \pm 7.0$ & $8.0 \pm 3.5$ & 0.0 & $0.5 \pm 0.5$ & $0.5 \pm 0.5$ \\
\hline & $\mathrm{T} 45$ & KA & $A a / C s$ & B & $38.4 \pm 4.1$ & $34.8 \pm 3.7$ & 0.0 & $0.5 \pm 0.5$ & $3.6 \pm 1.7$ \\
\hline & T69 & KA & $A a$ & B & $17.8 \pm 4.0$ & $14.9 \pm 3.4$ & 0.0 & 0.0 & $0.5 \pm 0.5$ \\
\hline & $\mathrm{T} 1$ & KA & - & A & $11.5 \pm 4.0$ & $3.0 \pm 1.7$ & 0.0 & 0.0 & 0.0 \\
\hline & $\mathrm{T} 3$ & KA & - & A & $49.0 \pm 2.0$ & $0.5 \pm 0.5$ & 0.0 & 0.0 & 0.0 \\
\hline & $\mathrm{T} 76$ & $\mathrm{Sb}$ & - & A & $12.5 \pm 4.2$ & $3.0 \pm 1.0$ & 0.0 & $3.0 \pm 3.0$ & 0.0 \\
\hline & $\mathrm{T} 77$ & $\mathrm{Sb}$ & - & A & $62.0 \pm 5.0$ & $37.5 \pm 5.0$ & 0.0 & 0.0 & $6.5 \pm 2.0$ \\
\hline & $\mathrm{T} 78$ & $\mathrm{Sb}$ & - & A & $37.0 \pm 4.0$ & $10.5 \pm 2.1$ & 0.0 & 0.0 & 0.0 \\
\hline & $\mathrm{T} 79$ & $\mathrm{Sb}$ & - & A & $18.5 \pm 4.7$ & 0.0 & 0.0 & 0.0 & 0.0 \\
\hline & $\mathrm{T} 80$ & $\mathrm{Sb}$ & - & A & $63.0 \pm 5.2$ & $1.5 \pm 1.0$ & 0.0 & 0.0 & 0.0 \\
\hline & $\mathrm{T} 6$ & Ut & - & A & $10.5 \pm 5.3$ & 0.0 & 0.0 & 0.0 & 0.0 \\
\hline & $\mathrm{T} 16$ & Ut & - & A & $15.5 \pm 3.2$ & $1.5 \pm 0.8$ & 0.0 & 0.0 & 0.0 \\
\hline & T38 & Ut & - & A & $5.0 \pm 1.3$ & $1.0 \pm 0.6$ & 0.0 & 0.0 & $1.0 \pm 0.6$ \\
\hline & $\mathrm{T} 40$ & Ut & - & A & $4.5 \pm 2.4$ & 0.0 & 0.0 & 0.0 & 0.0 \\
\hline & T58 & $\mathrm{Ut}$ & - & A & $27.0 \pm 4.9$ & $17.0 \pm 4.0$ & 0.0 & $5.0 \pm 2.2$ & $1.5 \pm 0.8$ \\
\hline & T66 & Ut & - & A & $33.5 \pm 5.6$ & $11.5 \pm 3.5$ & 0.0 & 0.0 & 0.0 \\
\hline & $\mathrm{T} 70$ & Ut & - & A & $32.5 \pm 4.5$ & $17.0 \pm 4.7$ & 0.0 & 0.0 & 0.0 \\
\hline & $\mathrm{T} 81$ & Ut & - & A & $35.0 \pm 5.7$ & $7.0 \pm 2.4$ & 0.0 & $0.5 \pm 0.5$ & 0.0 \\
\hline & $\mathrm{T} 23$ & $\mathrm{Sa}$ & - & A & $21.5 \pm 6.3$ & 0.0 & 0.0 & 0.0 & 0.0 \\
\hline & $\mathrm{T} 24$ & $\mathrm{Sa}$ & - & A & $6.0 \pm 1.6$ & $2.0 \pm 1.1$ & 0.0 & 0.0 & $0.5 \pm 0.5$ \\
\hline & $\mathrm{T} 26$ & $\mathrm{Sa}$ & - & A & $9.0 \pm 1.6$ & $5.5 \pm 1.5$ & 0.0 & $0.5 \pm 0.5$ & $0.5 \pm 0.5$ \\
\hline & $\mathrm{T} 28$ & $\mathrm{Sa}$ & - & A & $14.0 \pm 3.0$ & $4.5 \pm 1.5$ & 0.0 & 0.0 & 0.0 \\
\hline & $\mathrm{T} 29$ & $\mathrm{Sa}$ & - & A & $8.5 \pm 2.0$ & $5.0 \pm 1.3$ & 0.0 & 0.0 & 0.0 \\
\hline & $\mathrm{T} 30$ & $\mathrm{Sa}$ & - & A & $13.0 \pm 4.4$ & $1.5 \pm 0.8$ & 0.0 & $0.5 \pm 0.5$ & $0.5 \pm 0.5$ \\
\hline \multirow[t]{30}{*}{ Italy } & $\mathrm{I} 2$ & $\mathrm{Ca}$ & $A a / C s$ & $\mathrm{C}$ & $85.0 \pm 2.6$ & $9.5 \pm 3.3$ & 0.0 & 0.0 & $85.0 \pm 2.6$ \\
\hline & $\mathrm{I} 3$ & $\mathrm{Ca}$ & - & A & $2.5 \pm 2.0$ & $0.5 \pm 0.5$ & 0.0 & 0.0 & 0.0 \\
\hline & I4 & $\mathrm{Ca}$ & $A a$ & B & $19.0 \pm 3.3$ & $1.5 \pm 1.5$ & 0.0 & 0.0 & 0.0 \\
\hline & I5 & $\mathrm{Ca}$ & $A a / C s$ & $\mathrm{C}$ & $65.7 \pm 8.4$ & $4.6 \pm 1.8$ & 0.0 & 0.0 & $11.4 \pm 2.5$ \\
\hline & I8 & $\mathrm{Ca}$ & $A a$ & $\mathrm{C}$ & $36.0 \pm 3.5$ & $2.0 \pm 0.9$ & 0.0 & 0.0 & 0.0 \\
\hline & $\mathrm{I} 12$ & $\mathrm{Ca}$ & $A a$ & B & $53.5 \pm 5.9$ & $10.5 \pm 3.4$ & 0.0 & 0.0 & 0.0 \\
\hline & I13 & $\mathrm{Ca}$ & $A a$ & B & $40.0 \pm 3.7$ & $6.8 \pm 2.4$ & 0.0 & 0.0 & 0.0 \\
\hline & I16 & $\mathrm{Ca}$ & - & A & $29.0 \pm 4.1$ & $1.0 \pm 1.0$ & 0.0 & 0.0 & 0.0 \\
\hline & I17 & Os & Sc/Aa & B & $6.0 \pm 3.2$ & $3.1 \pm 1.7$ & 0.0 & $0.5 \pm 0.5$ & 0.0 \\
\hline & I18 & Os & Sc/Aa & B & $33.8 \pm 4.1$ & $19.7 \pm 3.7$ & 0.0 & $1.5 \pm 1.1$ & 0.0 \\
\hline & I19 & Os & Sc/Aa & B & $30.7 \pm 4.1$ & $20.3 \pm 5.2$ & 0.0 & 0.0 & 0.0 \\
\hline & $\mathrm{I} 20$ & Os & Sc/Aa & B & $38.9 \pm 5.2$ & $32.2 \pm 4.3$ & 0.0 & 0.0 & 0.0 \\
\hline & I 21 & Os & Sc/Aa & B & $27.7 \pm 6.0$ & $9.0 \pm 3.0$ & 0.0 & $0.4 \pm 0.4$ & 0.0 \\
\hline & $\mathrm{I} 22$ & Os & - & A & $22.8 \pm 3.2$ & $11.1 \pm 2.0$ & 0.0 & 0.0 & 0.0 \\
\hline & $\mathrm{I} 23$ & Os & - & A & $21.7 \pm 4.2$ & $13.5 \pm 4.1$ & 0.0 & $2.2 \pm 1.7$ & $0.4 \pm 0.4$ \\
\hline & $\mathrm{I} 24$ & Os & - & A & $22.6 \pm 3.1$ & $11.7 \pm 2.4$ & 0.0 & 0.0 & 0.0 \\
\hline & $\mathrm{I} 25$ & Os & Sc/Aa & B & $25.1 \pm 3.7$ & $6.9 \pm 2.1$ & 0.0 & $1.6 \pm 1.0$ & 0.0 \\
\hline & $\mathrm{I} 26$ & Os & $S c / A a$ & B & $20.3 \pm 3.1$ & $3.6 \pm 1.5$ & 0.0 & 0.0 & 0.0 \\
\hline & I 27 & Os & SclAa & B & $12.7 \pm 3.4$ & $3.4 \pm 1.8$ & 0.0 & $3.9 \pm 2.2$ & 0.0 \\
\hline & $\mathrm{I} 28$ & Os & $A a$ & B & $14.9 \pm 3.8$ & $9.5 \pm 3.0$ & 0.0 & $2.7 \pm 2.2$ & 0.0 \\
\hline & I 29 & $\mathrm{Re}$ & $A a / C s$ & B & $73.0 \pm 3.3$ & $62.0 \pm 4.3$ & 0.0 & 0.0 & $2.0 \pm 1.1$ \\
\hline & $\mathrm{I} 30$ & $\mathrm{Re}$ & $A a$ & $\mathrm{C}$ & $77.5 \pm 3.9$ & $69.5 \pm 5.6$ & 0.0 & 0.0 & 0.0 \\
\hline & $\mathrm{I} 31$ & $\mathrm{Re}$ & $A a / C s$ & $\mathrm{C}$ & $65.0 \pm 4.2$ & $52.0 \pm 4.4$ & 0.0 & 0.0 & $11.0 \pm 2.2$ \\
\hline & $\mathrm{I} 32$ & $\mathrm{Re}$ & - & A & $18.0 \pm 2.8$ & 0.0 & 0.0 & 0.0 & 0.0 \\
\hline & $\mathrm{I} 33$ & $\mathrm{Re}$ & $A a$ & B & $30.5 \pm 2.9$ & $24.5 \pm 3.1$ & 0.0 & 0.0 & 0.0 \\
\hline & $\mathrm{I} 34$ & $\mathrm{Re}$ & $A a$ & B & $48.5 \pm 3.5$ & $32.5 \pm 3.3$ & 0.0 & 0.0 & 0.0 \\
\hline & $\mathrm{I} 35$ & Mo & - & A & $21.0 \pm 3.6$ & $13.5 \pm 2.2$ & 0.0 & $3.0 \pm 1.6$ & 0.0 \\
\hline & $\mathrm{I} 36$ & Mo & - & A & $38.5 \pm 2.8$ & $36.5 \pm 3.2$ & 0.0 & $1.0 \pm 0.9$ & 0.0 \\
\hline & $\mathrm{I} 37$ & $\mathrm{Ba}$ & - & A & $47.5 \pm 3.2$ & $36.0 \pm 3.9$ & 0.0 & 0.0 & $1.0 \pm 0.6$ \\
\hline & & & & & & & & (Contin & next page) \\
\hline
\end{tabular}

a $\mathrm{SH}=$ Sidi Hmada, KA = Kalâat El-Andalous, $\mathrm{Sb}=$ Sbeïtla, Ut = Utique, $\mathrm{Sa}=$ Sahline, $\mathrm{Ca}=\mathrm{Castelfidardo}, \mathrm{Os}=\mathrm{Osimo}, \mathrm{Re}=\mathrm{Recanati}, \mathrm{Mo}=\mathrm{Monopoli}$, and Ba = Baranello.

b $S c=$ Stagonosporopsis cucurbitacearum, Aa = Alternaria alternata, $F s=F$. solani, and Cs = Curvularia spicifera .

c $\mathrm{A}=$ asymptomatic fruit, $\mathrm{B}=$ infected fruit showing lesion on squash skin without colonization of fruit cavity, and $\mathrm{C}=$ infected fruit showing lesion that has colonized fruit cavity.

d Data are means \pm SE. As $=$ Alternaria solani, Ab $=$ Aspergillus brasiliensis, $P h$ sp. $=$ Phoma sp., Ff $=$ Fusarium fujikuroi, Fo $=F$. oxysporum, Fi $=F$. incarnatum,

$\operatorname{Pr}=$ Paramyrothecium roridum, Av = Albifimbria verrucaria, $S v=$ Stemphylium vesicarium, and Rs $=R$ Rizopus stolonifera .

e The same seed can be infected by more than one fungus. 
Table 6. (Continued from previous page)

\begin{tabular}{|c|c|c|c|c|c|c|c|c|c|}
\hline \multicolumn{10}{|c|}{ Incidence of fungal species $(\%)^{d}$} \\
\hline$S c$ & $P h$ sp. & $F f$ & Fo & $F i$ & Fs & $P r$ & $A v$ & $S v$ & $R s$ \\
\hline $44.0 \pm 4.5$ & $2.5 \pm 2.5$ & $8.5 \pm 2.3$ & $2.0 \pm 1.4$ & $0.5 \pm 0.5$ & $9.0 \pm 2.5$ & 0.0 & 0.0 & $0.5 \pm 0.5$ & $2.5 \pm 2.5$ \\
\hline $57.0 \pm 4.1$ & $3.0 \pm 1.3$ & $10.5 \pm 2.5$ & $1.5 \pm 1.1$ & 0.0 & $13.5 \pm 4.2$ & $1.0 \pm 1.0$ & $2.0 \pm 1.2$ & 0.0 & $1.5 \pm 1.5$ \\
\hline $21.5 \pm 4.5$ & 0.0 & $8.5 \pm 2.9$ & 0.0 & 0.0 & $6.0 \pm 3.4$ & 0.0 & 0.0 & 0.0 & $6.5 \pm 2.1$ \\
\hline $62.0 \pm 4.2$ & $1.0 \pm 1.0$ & $2.0 \pm 2.0$ & $1.0 \pm 0.7$ & 0.0 & $0.5 \pm 05$ & 0.0 & 0.0 & 0.0 & 0.0 \\
\hline $4.0 \pm 4.0$ & $1.0 \pm 1.0$ & $5.5 \pm 3.4$ & 0.0 & $2.0 \pm 1.2$ & $6.0 \pm 3.8$ & $1.0 \pm 1.0$ & $1.5 \pm 1.5$ & $4.5 \pm 4.5$ & $8.5 \pm 6.0$ \\
\hline $4.5 \pm 1.5$ & 0.0 & $16.0 \pm 5.9$ & 0.0 & 0.0 & $9.5 \pm 4.9$ & 0.0 & 0.0 & $3.5 \pm 1.1$ & $3.5 \pm 1.8$ \\
\hline 0.0 & 0.0 & $4.5 \pm 2.2$ & $1.0 \pm 1.0$ & 0.0 & $10.5 \pm 3.0$ & $4.5 \pm 2.1$ & $15.5 \pm 4.6$ & $3.0 \pm 1.3$ & $0.5 \pm 0.5$ \\
\hline $3.5 \pm 1.7$ & $1.0 \pm 0.7$ & $7.0 \pm 3.0$ & $1.0 \pm 0.7$ & $1.5 \pm 1.1$ & $0.0 \mathrm{~b}$ & $3.0 \pm 1.8$ & $7.0 \pm 1.9$ & $1.0 \pm 0.7$ & $9.5 \pm 3.8$ \\
\hline 0.0 & 0.0 & $1.5 \pm 0.8$ & 0.0 & 0.0 & 0.0 & 0.0 & 0.0 & $12.5 \pm 0.7$ & $29.5 \pm 7.6$ \\
\hline 0.0 & 0.0 & 0.0 & 0.0 & 0.0 & 0.0 & 0.0 & 0.0 & $1.0 \pm 0.7$ & $32.0 \pm 4.6$ \\
\hline 0.0 & 0.0 & $4.0 \pm 1.5$ & $3.0 \pm 1.8$ & $0.5 \pm 0.5$ & $6.5 \pm 2.0$ & 0.0 & 0.0 & 0.0 & 0.0 \\
\hline 0.0 & 0.0 & $2.5 \pm 1.0$ & 0.0 & 0.0 & 0.0 & 0.0 & 0.0 & $1.0 \pm 0.7$ & $30.5 \pm 5.4$ \\
\hline 0.0 & 0.0 & $7.5 \pm 3.0$ & 0.0 & 0.0 & 0.0 & 0.0 & 0.0 & $2.5 \pm 1.0$ & $17.5 \pm 4.9$ \\
\hline 0.0 & 0.0 & $0.5 \pm 0.5$ & 0.0 & 0.0 & 0.0 & 0.0 & 0.0 & 0.0 & $12.0 \pm 4.7$ \\
\hline 0.0 & 0.0 & 0.0 & 0.0 & 0.0 & 0.0 & 0.0 & 0.0 & 0.0 & 0.0 \\
\hline 0.0 & 0.0 & 0.0 & 0.0 & 0.0 & 0.0 & 0.0 & 0.0 & $3.0 \pm 1.2$ & $6.0 \pm 2.0$ \\
\hline 0.0 & 0.0 & $1.0 \pm 0.6$ & 0.0 & 0.0 & 0.0 & 0.0 & 0.0 & $3.5 \pm 1.3$ & $5.0 \pm 3.0$ \\
\hline 0.0 & 0.0 & $48.5 \pm 2.0$ & 0.0 & 0.0 & 0.0 & 0.0 & 0.0 & 0.0 & $1.0 \pm 1.0$ \\
\hline $0.5 \pm 0.5$ & 0.0 & $0.5 \pm 0.5$ & 0.0 & 0.0 & $4 \pm 3$ & 0.0 & 0.0 & 0.0 & $1.5 \pm 0.8$ \\
\hline $9.0 \pm 2.5$ & 0.0 & 0.0 & 0.0 & 0.0 & $6.5 \pm 2.0$ & 0.0 & 0.0 & $4.5 \pm 1.8$ & 0.0 \\
\hline $2.5 \pm 1.2$ & 0.0 & $9.0 \pm 3.0$ & $1.0 \pm 1.0$ & $1.0 \pm 0.6$ & $13.0 \pm 4.2$ & 0.0 & 0.0 & 0.0 & $1.5 \pm 1.0$ \\
\hline $0.5 \pm 0.5$ & 0.0 & 0.0 & 0.0 & 0.0 & $18.0 \pm 4.7$ & 0.0 & 0.0 & 0.0 & 0.0 \\
\hline 0.0 & 0.0 & 0.0 & $1.0 \pm 1.0$ & 0.0 & $59.5 \pm 6.0$ & 0.0 & 0.0 & 0.0 & $1.5 \pm 1.0$ \\
\hline 0.0 & 0.0 & 0.0 & 0.0 & 0.0 & 0.0 & 0.0 & 0.0 & 0.0 & $10.5 \pm 5.3$ \\
\hline $3.0 \pm 1.2$ & 0.0 & $4.0 \pm 1.6$ & 0.0 & 0.0 & 0.0 & 0.0 & 0.0 & $0.5 \pm 0.5$ & $6.5 \pm 2.2$ \\
\hline 0.0 & 0.0 & $0.5 \pm 0.5$ & 0.0 & 0.0 & 0.0 & 0.0 & 0.0 & $0.5 \pm 0.5$ & $2.5 \pm 1.2$ \\
\hline 0.0 & 0.0 & 0.0 & 0.0 & 0.0 & 0.0 & 0.0 & 0.0 & 0.0 & $4.5 \pm 2.4$ \\
\hline $0.5 \pm 0.5$ & 0.0 & 0.0 & 0.0 & $0.5 \pm 0.5$ & $2.5 \pm 2.5$ & 0.0 & 0.0 & 0.0 & $0.5 \pm 0.5$ \\
\hline $1.0 \pm 0.6$ & 0.0 & $4.5 \pm 1.1$ & $2.0 \pm 1.5$ & $2.5 \pm 1.7$ & $12.0 \pm 3.6$ & 0.0 & 0.0 & 0.0 & $0.5 \pm 0.5$ \\
\hline $0.5 \pm 0.5$ & 0.0 & $11.5 \pm 2.8$ & 0.0 & $1.5 \pm 0.8$ & $1.0 \pm 0.6$ & 0.0 & 0.0 & $1.0 \pm 1.0$ & $1.0 \pm 0.6$ \\
\hline 0.0 & 0.0 & $25.0 \pm 5.1$ & 0.0 & 0.0 & 0.0 & 0.0 & 0.0 & $0.5 \pm 0.5$ & $1.0 \pm 1.0$ \\
\hline 0.0 & 0.0 & $20.0 \pm 6.3$ & 0.0 & 0.0 & 0.0 & 0.0 & 0.0 & 0.0 & $1.5 \pm 1.4$ \\
\hline 0.0 & 0.0 & $1.5 \pm 1.0$ & 0.0 & 0.0 & 0.0 & 0.0 & 0.0 & $0.5 \pm 0.5$ & $1.5 \pm 1.0$ \\
\hline 0.0 & 0.0 & 0.0 & 0.0 & $0.5 \pm 0.5$ & $1.0 \pm 0.6$ & 0.0 & 0.0 & 0.0 & $1.5 \pm 0.8$ \\
\hline 0.0 & 0.0 & $0.5 \pm 0.5$ & 0.0 & 0.0 & 0.0 & 0.0 & 0.0 & 0.0 & $7.0 \pm 1.9$ \\
\hline 0.0 & 0.0 & 0.0 & 0.0 & 0.0 & 0.0 & 0.0 & 0.0 & 0.0 & $3.0 \pm 1.4$ \\
\hline 0.0 & 0.0 & $0.5 \pm 0.5$ & 0.0 & 0.0 & 0.0 & 0.0 & 0.0 & $2.0 \pm 0.9$ & $8.0 \pm 4.0$ \\
\hline 0.0 & 0.0 & $9.5 \pm 2.5$ & 0.0 & 0.0 & 0.0 & 0.0 & 0.0 & 0.0 & 0.0 \\
\hline 0.0 & 0.0 & 0.0 & 0.0 & 0.0 & 0.0 & 0.0 & 0.0 & 0.0 & $2.0 \pm 2.0$ \\
\hline 0.0 & 0.0 & $12.0 \pm 2.5$ & 0.0 & 0.0 & 0.0 & 0.0 & 0.0 & 0.0 & $4.5 \pm 2.7$ \\
\hline 0.0 & 0.0 & $53.9 \pm 7.2$ & 0.0 & 0.0 & 0.0 & 0.0 & 0.0 & 0.0 & 0.0 \\
\hline 0.0 & 0.0 & $17.2 \pm 3.8$ & 0.0 & 0.0 & 0.0 & 0.0 & 0.0 & 0.0 & 0.0 \\
\hline 0.0 & 0.0 & $13.5 \pm 5.2$ & 0.0 & 0.0 & 0.0 & 0.0 & 0.0 & $1.0 \pm 0.6$ & $29.0 \pm 5.1$ \\
\hline 0.0 & 0.0 & $21.5 \pm 4.1$ & 0.0 & 0.0 & 0.0 & 0.0 & 0.0 & 0.0 & $11.5 \pm 3.5$ \\
\hline 0.0 & 0.0 & $27.0 \pm 4.0$ & 0.0 & 0.0 & 0.0 & 0.0 & 0.0 & 0.0 & $1.5 \pm 1.5$ \\
\hline 0.0 & 0.0 & $0.6 \pm 0.6$ & 0.0 & $0.4 \pm 0.4$ & 0.0 & 0.0 & 0.0 & 0.0 & $1.1 \pm 1.1$ \\
\hline 0.0 & 0.0 & $9.3 \pm 3.1$ & 0.0 & $1.5 \pm 1.1$ & 0.0 & 0.0 & 0.0 & $0.5 \pm 0.5$ & 0.0 \\
\hline 0.0 & 0.0 & $8.8 \pm 2.9$ & 0.0 & $1.5 \pm 1.0$ & 0.0 & 0.0 & 0.0 & $1.0 \pm 0.6$ & 0.0 \\
\hline 0.0 & 0.0 & $0.9 \pm 0.6$ & 0.0 & $0.9 \pm 0.6$ & 0.0 & 0.0 & $1.9 \pm 1.4$ & $2.4 \pm 0.8$ & 0.0 \\
\hline 0.0 & 0.0 & $10.0 \pm 3.9$ & 0.0 & 0.0 & 0.0 & 0.0 & 0.0 & $0.4 \pm 0.4$ & $7.6 \pm 4.8$ \\
\hline 0.0 & 0.0 & $10.5 \pm 2.6$ & 0.0 & 0.0 & 0.0 & 0.0 & 0.0 & 0.0 & 0.0 \\
\hline 0.0 & 0.0 & $4.0 \pm 1.9$ & 0.0 & 0.0 & 0.0 & 0.0 & 0.0 & $0.4 \pm 0.4$ & 0.0 \\
\hline 0.0 & 0.0 & $9.5 \pm 3.1$ & 0.0 & $0.4 \pm 0.4$ & 0.0 & 0.0 & $0.4 \pm 0.4$ & 0.0 & $0.4 \pm 0.4$ \\
\hline 0.0 & 0.0 & $14.9 \pm 3.8$ & 0.0 & 0.0 & 0.0 & 0.0 & 0.0 & 0.0 & $1 \pm 1$ \\
\hline 0.0 & 0.0 & $15.3 \pm 3.6$ & 0.0 & $1.3 \pm 0.9$ & 0.0 & 0.0 & 0.0 & 0.0 & 0.0 \\
\hline 0.0 & 0.0 & 0.0 & 0.0 & 0.0 & 0.0 & 0.0 & 0.0 & 0.0 & $5.3 \pm 2.5$ \\
\hline 0.0 & 0.0 & $2.2 \pm 1.8$ & 0.0 & 0.0 & 0.0 & 0.0 & 0.0 & 0.0 & $0.4 \pm 0.4$ \\
\hline 0.0 & 0.0 & $22.0 \pm 3.8$ & 0.0 & 0.0 & 0.0 & $1.0 \pm 1.0$ & 0.0 & $8.5 \pm 2.3$ & 0.0 \\
\hline 0.0 & 0.0 & $46.0 \pm 6.1$ & 0.0 & $1 \pm 1$ & 0.0 & $0.5 \pm 0.5$ & 0.0 & $1.0 \pm 0.6$ & 0.0 \\
\hline 0.0 & 0.0 & $9.5 \pm 3.5$ & 0.0 & 0.0 & 0.0 & 0.0 & 0.0 & $2.5 \pm 1.2$ & 0.0 \\
\hline 0.0 & 0.0 & $18.0 \pm 2.8$ & 0.0 & 0.0 & 0.0 & 0.0 & 0.0 & 0.0 & 0.0 \\
\hline 0.0 & 0.0 & $3.5 \pm 1.5$ & 0.0 & 0.0 & 0.0 & $3.0 \pm 1.4$ & 0.0 & $0.5 \pm 0.5$ & 0.0 \\
\hline 0.0 & 0.0 & $21.5 \pm 4.1$ & 0.0 & 0.0 & 0.0 & 0.0 & 0.0 & 0.0 & 0.0 \\
\hline 0.0 & 0.0 & $1.5 \pm 1.5$ & 0.0 & 0.0 & 0.0 & 0.0 & 0.0 & $1.0 \pm 1.0$ & 0.0 \\
\hline 0.0 & 0.0 & $14.5 \pm 3.4$ & 0.0 & 0.0 & 0.0 & 0.0 & $1.5 \pm 1.0$ & 0.0 & 0.0 \\
\hline 0.0 & 0.0 & $8.0 \pm 1.3$ & 0.0 & 0.0 & 0.0 & $1.5 \pm 1.0$ & 0.0 & $3.0 \pm 1.2$ & 0.0 \\
\hline
\end{tabular}


large-scale spread of these pathogens and to their introduction into new planting areas. Therefore, cultural practices such as visual inspection for absence of lesions on fruit are not sufficient to ensure that seeds are not infected. Thomas-Sharma et al. (2017) showed that the selection of healthy plants in the field is an important step to obtain seeds of good quality. In addition, eight symptomatic fruits in Italy were infected by Stagonosporopsis cucurbitacearum, but the seeds obtained from these fruits were not infected by this pathogen.
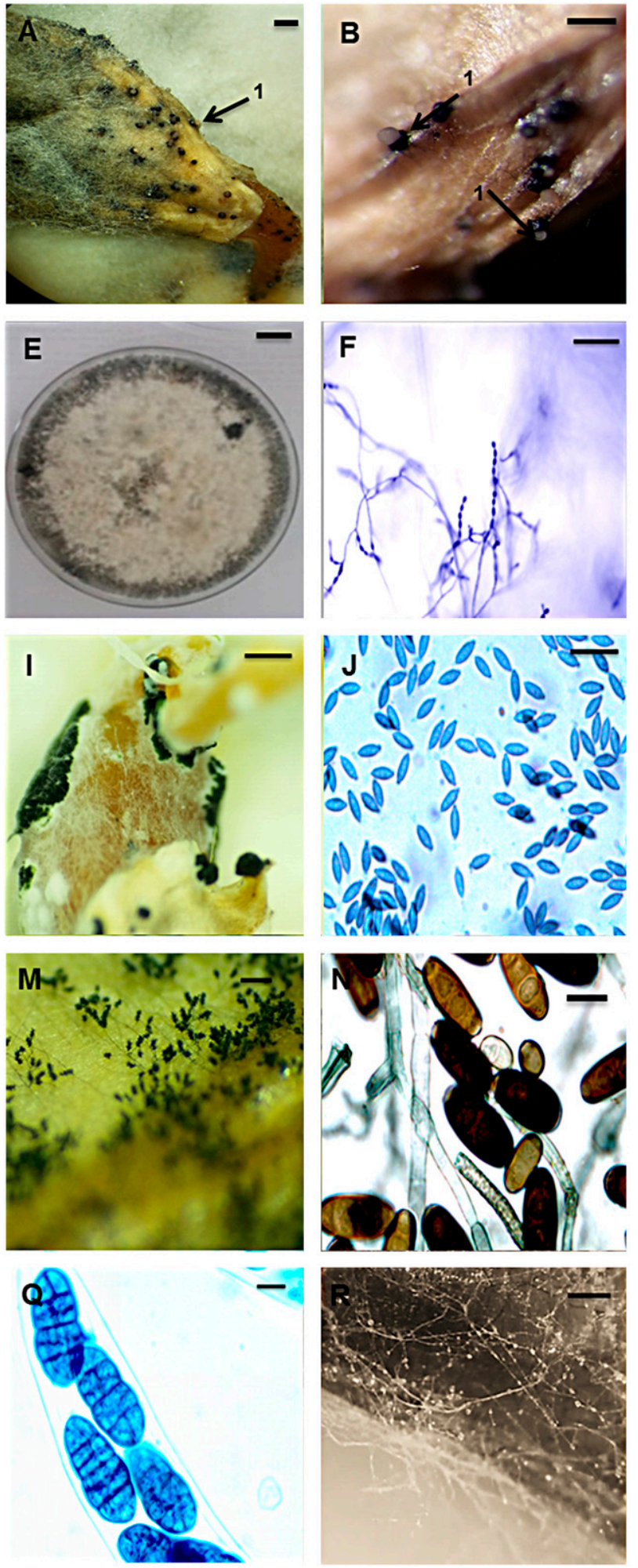
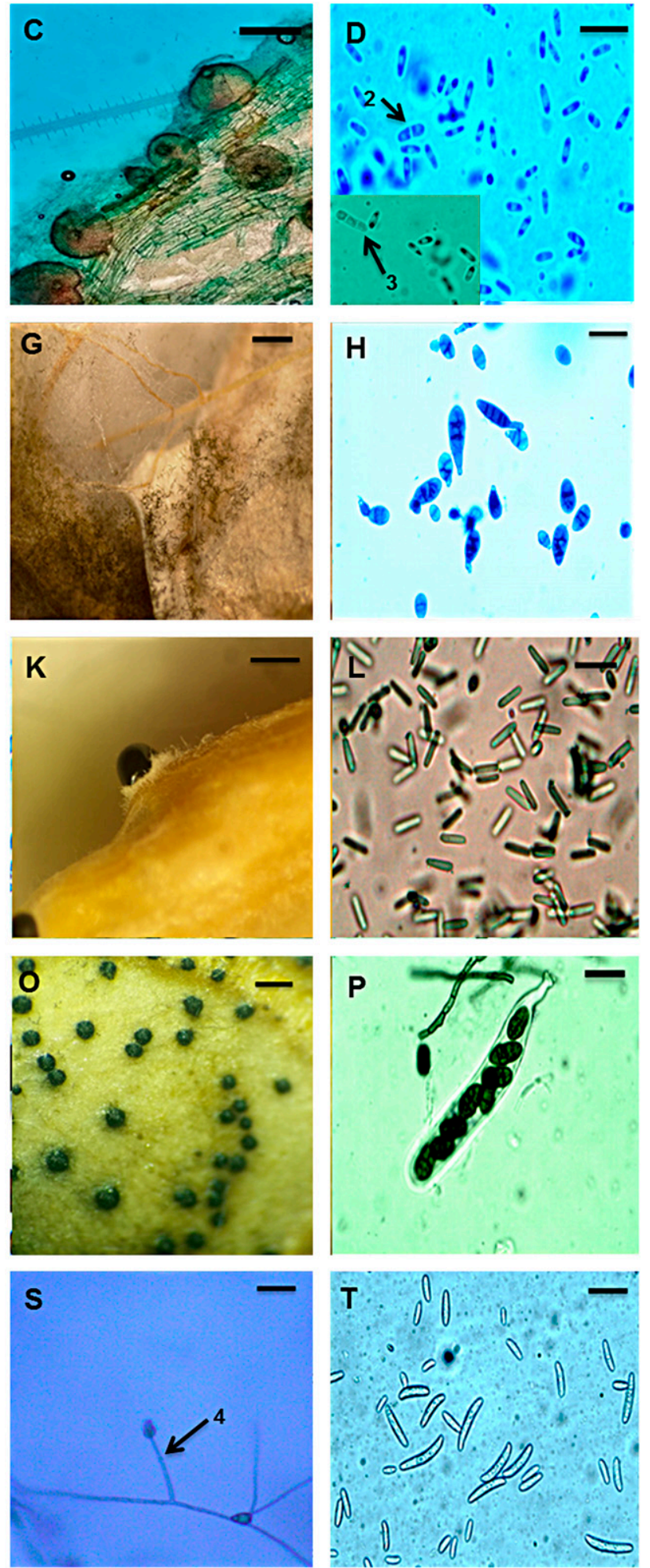

Fig. 3. A and B, Pycnidia of Stagonosporopsis cucurbitacearum on a seed from a squash, as seen under the stereomicroscope, with the ooze of pycnidiospores indicated (arrow 1). C, Pycnidia under the microscope. D, Pycnidiospores: cylindrical, mostly nonseptate, few uniseptate (arrow 2) and biseptate (inset, arrow 3). E, Ten-day-old colony on potato dextrose agar at $22 \pm 2^{\circ} \mathrm{C}$. F and G, Long chains of conidia of Alternaria alternata on seeds. H, Conidia of Alternaria alternata. I, Sporodochia of Albifimbria verrucaria on seed. J, Elliptical conidia of Albifimbria verrucaria. K, Sporodochia of Paramyrothecium roridum on a squash seed. L, Cylindrical conidia of Paramyrothecium roridum. M, Conidia of Curvularia spicifera on a seed, as seen under the stereomicroscope. $\mathbf{N}$, Conidia and vegetative hyphae of Curvularia spicifera. $\mathbf{0}$, Perithecia of Stemphylium vesicarium on a seed. P, An ascus of Stemphylium vesicarium, with a short, broad pedicel bearing eight ascospores. Q, Ascospores of Stemphylium vesicarium. R, Fusarium solani on a seed. S, Long phialide of $F$. solani (arrow 4). T, Microconidia and macroconidia of $F$. solani. Scale bars $=200 \mu \mathrm{m}$ in A, B, I, M, and R; $100 \mu \mathrm{m}$ in C, F, and K; $10 \mu \mathrm{m}$ in D, J, L, and N; $1 \mathrm{~cm}$ in E; $400 \mu \mathrm{m}$ in $\mathrm{G}$ and $\mathrm{O} ; 20 \mu \mathrm{m}$ in H, P, and T; $5 \mu \mathrm{m}$ in Q; and $25 \mu \mathrm{m}$ in $\mathrm{S}$. 
The likely explanation for this is that the spatial development of a pathogen is influenced by many factors such as inoculum source (e.g., infested soil) and environmental conditions (e.g., relative humidity); for example, Stagonosporopsis cucurbitacearum is influenced by the environmental conditions during sampling (Rennberger et al. 2018).

Correct identification of fungal pathogens is a key factor for crop protection and for the development of disease management strategies

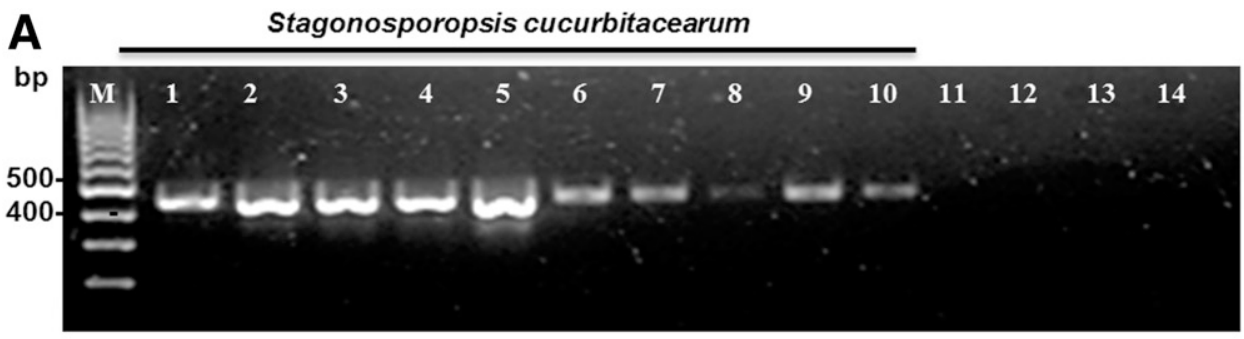

B

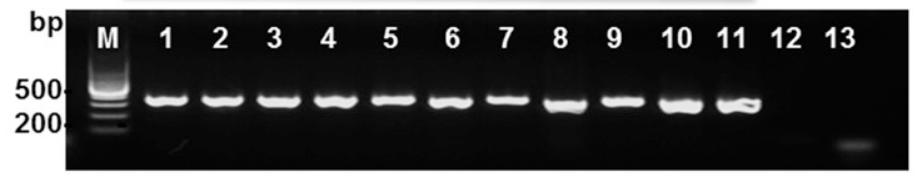

D

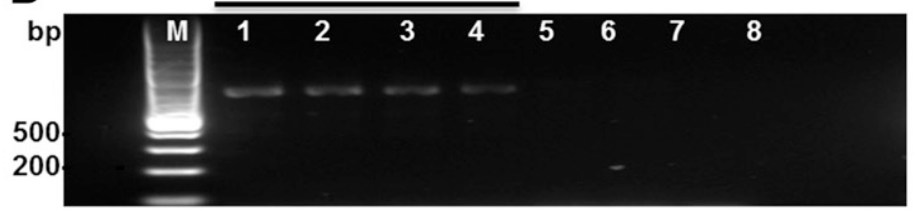

C Curvularia spicifera

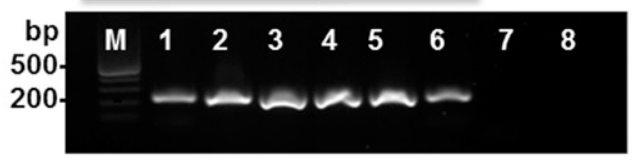

E

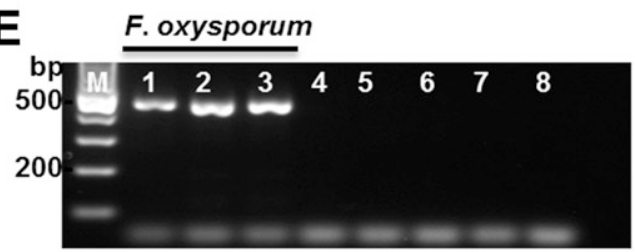

Fig. 4. A, Specificity of the primer pair RGII F/RGII R used for detection of Stagonosporopsis cucurbitacearum in group RGII. Lanes 1 to 10, Stagonosporopsis cucurbitacearum (isolates D33, D29, D21, D5, D42, D49, D45, D12, DBF1, and DBF2, respectively); lane 11, Phoma sp. (isolate Ph39); lane 12, Alternaria alternata (isolate A15); lane 13, Curvularia spicifera (isolate C170); and lane 14, water controls. B, Specificity of the primer pair AAF2/AAR3 for detection of Alternaria alternata. Lanes 1 to 11, Alternaria alternata (isolates A38, A15, A17, A5, A59, IA1, IA3, IA7, IA10, IA2, and IA5, respectively); lane 12, Stemphylium vesicarium (isolate P66); and lane 13, water control. C, Specificity of the primer pair Bipol-1F/Bipol-1R for detection of Curvularia spicifera. Lanes 1 to 6, Curvularia spicifera (isolates B172, B170, IB41, IB2, IB3, and IB4, respectively); lane 7, Fusarium solani (isolate F174); and lane 8, water control. D, Specificity of the primer pair TEF-Fs4 F/TEF-Fs4 R for detection of F. solani. Lanes 1 to 4, F. solani (isolates F174, F82, F30, and F142, respectively); lane 5, F. oxysporum (isolate F19); lane 6, Stagonosporopsis cucurbitacearum (isolate D33); lane 7, Stemphylium vesicarium (isolate P66); and lane 8, water control. E, Specificity of the primer pair FC-1/FC-2 for detection of F. oxysporum. Lanes 1 to 3, F. oxysporum (isolates F59, F16, and F19, respectively); lane 4, F. solani (isolate F174); lane 5, Stagonosporopsis cucurbitacearum (isolate D33); lane 6, Stagonosporopsis cucurbitacearum (isolate P66); lane 7, Paramyrothecium roridum (isolate M123); and lane 8, water control. $M=$ molecular weight markers (100-bp intervals).

A

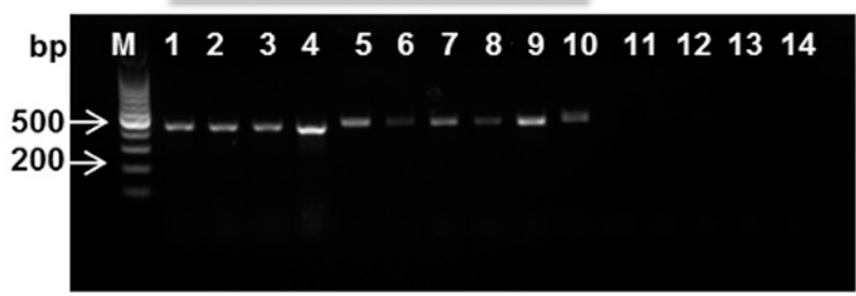

C

C

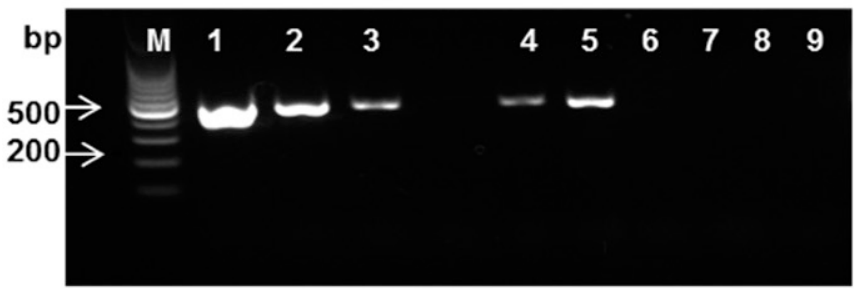

B

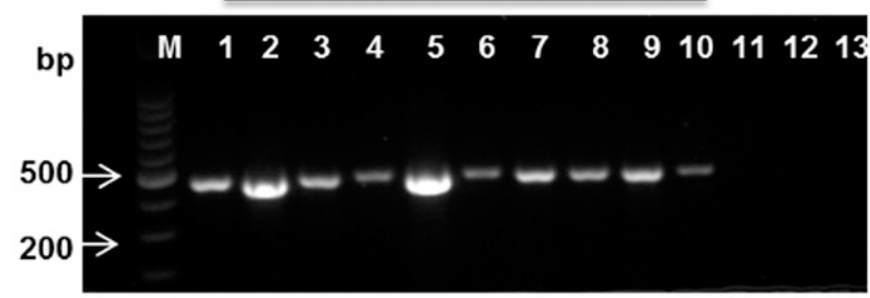

Pleospora herbarum

D

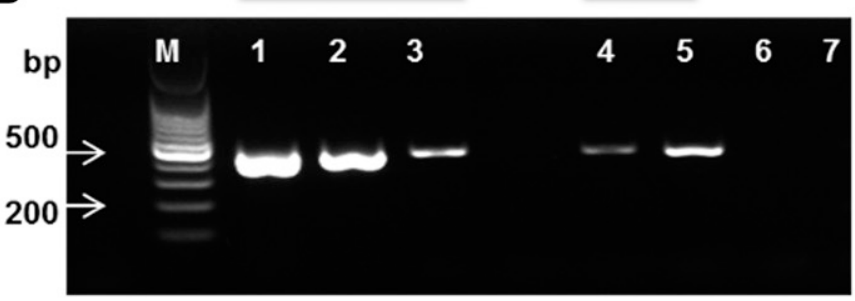

Fig. 5. Gel electrophoresis of PCR products generated with the designed specific primers for the detection of the fungi. A, Albifimbria verrucaria, with the primer pair Myroverr F1/ Myroverr R1. Lanes 1 to 10, Albifimbria verrucaria (isolates IAV1, IAV2, IAV3, IAV4, M149, M155, M144, M140, M135, and M146, respectively); lanes 11 to 13, Paramyrothecium roridum (isolates M123, M138, and M141, respectively); and lane 14, water control. B, Paramyrothecium roridum, with the primer pair Myroror F1/MyrororR1. Lanes 1 to 10, Paramyrothecium roridum (isolates IPR1, IPR4, IPR5, IPR6, IPR9, M73, M123, M138, M141, and M167, respectively); lanes 11 and 12, Albifimbria verrucaria (isolates M149 and M155, respectively); and lane 13, water control. C, Pleospora herbarum, with the primer pair Pleo F/Pleo R. Lanes 1 to 5, Pleospora herbarum (isolates IP4, IP5, P164, and P66, respectively); lanes 6 and 7, Alternaria alternata (isolates A38 and A15, respectively); lane 8, Curvularia spicifera (isolate B170); and lane 9, water control. D, Pleospora herbarum, with the primer pair Pleo F1/Pleo R1. Lanes 1 to 5, Pleospora herbarum (isolates IP41, IP4, IP5, P164, and P66, respectively); lane 6, Alternaria alternata (isolate A38); and lane 7, water control. $\mathrm{M}=$ molecular weight markers (100-bp intervals). 
Table 7. Incidence of seedborne fungi detected in the squash seed samples collected in Tunisia and Italy

\begin{tabular}{|c|c|c|c|c|c|c|c|c|c|c|}
\hline \multirow[b]{3}{*}{ Fungal species } & \multicolumn{10}{|c|}{ Disease incidence $(\%)^{\mathrm{a}}$} \\
\hline & \multicolumn{5}{|c|}{ Tunisia } & \multicolumn{5}{|c|}{ Italy } \\
\hline & SH & $\mathbf{K A}$ & Sb & $\mathbf{U t}$ & $\mathbf{S a}$ & $\mathbf{C a}$ & Os & $\mathbf{R e}$ & Mo & $\mathbf{B a}$ \\
\hline Alternaria alternata & $11.3 \pm 1.3$ & $25.1 \pm 1.8$ & $10.5 \pm 1.8$ & $6.8 \pm 1.0$ & $3.0 \pm 0.5$ & $4.2 \pm 0.7$ & $13.0 \pm 1.2$ & $40.0 \pm 2.6$ & $25 \pm 2.7$ & $36.0 \pm 4$ \\
\hline $\begin{array}{l}\text { Stagonosporopsis } \\
\text { cucurbitacearum }\end{array}$ & $24.6 \pm 2.3$ & 0.0 & $2.5 \pm 0.6$ & $0.6 \pm 0.2$ & 0.0 & 0.0 & 0.0 & 0.0 & 0.0 & 0.0 \\
\hline Rhizopus stolonifer & $4.1 \pm 1.0$ & $13.3 \pm 1.5$ & $0.9 \pm 0.3$ & $3.3 \pm 0.8$ & $3.7 \pm 0.8$ & $6.6 \pm 1.2$ & $1.3 \pm 0.5$ & 0.0 & $1.25 \pm 1.25$ & 0.0 \\
\hline Fusarium fujikuroi & $7.8 \pm 1.2$ & $6.5 \pm 1$ & $2.0 \pm 0.6$ & $6.3 \pm 1$ & $3.7 \pm 1.2$ & $20.8 \pm 1.8$ & $7.1 \pm 0.8$ & $20.0 \pm 2.0$ & $8.0 \pm 2.1$ & $8.0 \pm 1.3$ \\
\hline F. solani & $6.9 \pm 1.2$ & $0.6 \pm 0.2$ & $16.6 \pm 2.7$ & $1.9 \pm 0.6$ & $0.1 \pm 0.1$ & 0.0 & 0.0 & 0.0 & 0.0 & 0.0 \\
\hline $\begin{array}{l}\text { Albifimbria } \\
\text { verrucaria }\end{array}$ & $3.3 \pm 0.8$ & 0.0 & 0.0 & 0.0 & 0.0 & 0.0 & $0.2 \pm 0.1$ & 0.0 & $0.75 \pm 0.5$ & 0.0 \\
\hline $\begin{array}{l}\text { Stemphylium } \\
\text { vesicarium }\end{array}$ & $1.6 \pm 0.6$ & $2.3 \pm 0.7$ & $1.0 \pm 0.4$ & $0.3 \pm 0.1$ & $0.4 \pm 0.1$ & $0.1 \pm 0.09$ & $0.4 \pm 0.1$ & $2.0 \pm 0.5$ & $0.5 \pm 0.5$ & $3.0 \pm 1.2$ \\
\hline $\begin{array}{l}\text { Paramyrothecium } \\
\text { roridum }\end{array}$ & $1.2 \pm 0.4$ & 0.0 & 0.0 & 0.0 & 0.0 & 0.0 & 0.0 & $0.7 \pm 0.3$ & 0.0 & $1.5 \pm 1.0$ \\
\hline Phoma sp. & $1.1 \pm 0.4$ & 0.0 & 0.0 & 0.0 & 0.0 & 0.0 & 0.0 & 0.0 & 0.0 & 0.0 \\
\hline $\begin{array}{l}\text { Aspergillus } \\
\text { brasiliensis }\end{array}$ & $0.8 \pm 0.4$ & $1 \pm 0.2$ & $0.6 \pm 0.6$ & $0.06 \pm 0.06$ & $0.1 \pm 0.1$ & 0.0 & $1.0 \pm 0.3$ & 0.0 & $2.0 \pm 0.9$ & 0.0 \\
\hline F. oxysporum & $0.9 \pm 0.3$ & $0.3 \pm 0.1$ & $0.4 \pm 0.3$ & $0.2 \pm 0.1$ & 0.0 & 0.0 & 0.0 & 0.0 & 0.0 & 0.0 \\
\hline Curvularia spicifera & $0.7 \pm 0.3$ & $0.5 \pm 0.2$ & $1.3 \pm 0.5$ & $0.3 \pm 0.1$ & $0.2 \pm 0.1$ & $7.6 \pm 2.0$ & $0.03 \pm 0.03$ & $2.1 \pm 0.5$ & 0.0 & $1.0 \pm 0.6$ \\
\hline Alternaria solani & $0.8 \pm 0.4$ & 0.0 & 0.0 & 0.0 & 0.0 & 0.0 & 0.0 & 0.0 & 0.0 & 0.0 \\
\hline F. incarnatum & $0.5 \pm 0.2$ & $0.2 \pm 0.1$ & $0.2 \pm 0.1$ & $0.5 \pm 0.2$ & $0.08 \pm 0.08$ & 0.0 & $0.5 \pm 0.1$ & $0.1 \pm 0.1$ & 0.0 & 0.0 \\
\hline $\begin{array}{l}\text { Mean of infected } \\
\text { seeds }^{b}\end{array}$ & $55.6 \pm 2.2$ & $45.3 \pm 2.2$ & $36.6 \pm 2.7$ & $20.2 \pm 1.7$ & $11.6 \pm 1.5$ & $37.6 \pm 2.4$ & $23.0 \pm 1.3$ & $52.0 \pm 2.4$ & $29.7 \pm 2.7$ & $47.5 \pm 3.2$ \\
\hline
\end{tabular}

a Data are means \pm SE. $\mathrm{SH}=$ Sidi Hmada, $\mathrm{KA}=$ Kalâat El-Andalous, $\mathrm{Sb}=$ Sbeïlla, Ut $=$ Utique, $\mathrm{Sa}=\mathrm{Sahline}, \mathrm{Ca}=\mathrm{Castelfidardo}, \mathrm{Os}=\mathrm{Osimo}$, Re $=\mathrm{Recanati}, \mathrm{Mo}$ = Monopoli, and $\mathrm{Ba}=$ Baranello.

$\mathrm{b}$ The same seed can be infected by more than one fungus.

(Kusai et al. 2015). For this reason, ITS-rDNA, TUB, HIS, and EFl $\alpha$ sequence data were used here to confirm the morphological identification by Blast analysis and the homology of sequences in the NCBI database (Peay et al. 2008; White et al. 1990). For Stagonosporopsis cucurbitacearum, Alternaria alternata, Curvularia spicifera, F. oxysporum, and $F$. solani in particular, molecular detection was carried out using species-specific primers.

In our study, the application of RG-specific primers allowed us to determine that all Stagonosporopsis cucurbitacearum isolates from Tunisia and Italy belonged to the genetic group RGII; thus, none belonged to the genetic group RGI, which is prevalent in Florida and Georgia (Babu et al. 2015) and in Brazil (Santos et al. 2009). To our knowledge, there were no specific primers already available for the molecular identification of the genera Albifimbria, Paramyrothecium, and Stemphylium. In this study, species-specific primers were thus designed to identify Paramyrothecium roridum, Albifimbria verrucaria, and Stemphylium vesicarium. The ITS region of nuclear rDNA is the main genomic region targeted for PCR primer development (Guillemette et al. 2004). Myrothecium spp. have been detected in cucurbits, with identification through their morphological characteristics and through ITS sequence analysis (Fish et al. 2012; Sultana and Ghaffar 2009). In this study, ITS-specific primers for Paramyrothecium roridum, Albifimbria verrucaria, and Stemphylium vesicarium were used to identify the target microorganisms. The annealing temperatures of $60^{\circ} \mathrm{C}$ for Albifimbria verrucaria and Stemphylium vesicarium and $58^{\circ} \mathrm{C}$ for Paramyrothecium roridum allowed these pathogens to be specifically detected while preventing the amplification of other pathogens. To determine the sensitivity of each primer set designed in this study, serial dilutions of fungal genomic DNA of Albifimbria verrucaria, Paramyrothecium roridum, and Stemphylium vesicarium revealed that 40 ng of DNA was necessary to produce clear results on agarose gels. When we used $<4 \mathrm{ng}$ for Albifimbria verrucaria and Paramyrothecium roridum and $0.4 \mathrm{ng}$ for Stemphylium vesicarium, the molecular tools were not able to clearly identify the specific pathogens.

This study started from a phytosanitary survey that led to the identification of the main fruit rot and seedborne pathogens of squash through conventional and molecular diagnoses. The principal fungi present in the squash seeds in this study included Stagonosporopsis cucurbitacearum, Alternaria alternata, Albifimbria verrucaria, Paramyrothecium roridum, and Stemphylium vesicarium, and these were detected for the first time in Tunisia and Italy for seeds of Cucurbita maxima and Cucurbita moschata. These fungi are both seedborne and soilborne pathogens. The use of quality seeds is important for improving yields and conserving genetic material (Duan et al. 2007); consequently, the sanitary control of seeds is necessary to limit the spread of these pathogens. This can be achieved through application of seed-health testing methods, including conventional and molecular diagnostic tools. This technique has numerous positive characteristics, including rapidity, specificity, sensitivity, and ease of interpretation, which allow its application to the detection of seedborne pathogens (Mancini et al. 2016; Vannacci et al. 2014; Walcott 2003; Ward et al. 2004). Such data are useful for the identification of seedborne fungi directly in seed samples and for clarification of the risk of infection for the following crop. This study illustrates how fruit and plant selection can reduce the amount of seedborne pathogen inocula and can be used to obtain high-quality seeds, which can be a critical step in management strategies for sustainable agriculture.

\section{Acknowledgments}

We thank Professor Sebastiano Delfine for providing samples from Campobasso, and we also thank squash growers from the Italian and Tunisian regions for their kind cooperation.

\section{Literature Cited}

Ahmad, L., Pathak, N., and Zaidi, R. K. 2016. Antifungal potential of plant extracts against seed-borne fungi isolated from barley seeds (Hordeum vulgare L.). J. Plant Pathol. Microbiol. 7:350.

Arif, M., Chawla, S., Zaidi, N. W., Rayar, J. K., Variar, M., and Singh, U. S. 2012 Development of specific primers for genus Fusarium and $F$. solani using rDNA sub unit and transcription elongation factor (TEF $1 \alpha)$ gene. Afr. J. Biotechnol. 11:444-447.

Aveskamp, M. M., de Gruyter, J., Woudenberg, J. H. C., Verkley, G. J. M., and Crous, P. W. 2010. Highlights of the Didymellaceae: A polyphasic approach to characterize Phoma and related pleosporalean genera. Stud. Mycol. 65: $1-60$.

Babu, B., Kefialew, Y. W., Li, P.-F., Yang, X.-P., George, S., Newberry, E., Dufault, N., Abate, D., Ayalew, A., Marois, J., and Paret, M. L. 2015. Genetic characterization of Didymella bryoniae isolates infecting watermelon and other cucurbits in Florida and Georgia. Plant Dis. 99:1488-1499. 
Blanco, R., and Aveling, T. A. S. 2018. Seed-borne Fusarium pathogens in agricultural crops. Acta Hortic. 1204:161-170.

Booth, C. 1971. The Genus Fusarium. Commonwealth Mycological Institute, Kew, Surrey, United Kingdom.

Boughalleb, N., and El Mahjoub, M. 2006. In-vitro determination of Fusarium spp. infection on watermelon seeds and their localization. Plant Pathol. 5: 178-182.

Boughalleb, N., El Mahjoub, M., Abad-Campos, P., Pérez-Sierra, A., GarcíaJiménez, J., and Armengol, J. 2007. First report of gummy stem blight caused by Didymella bryoniae on grafted watermelon in Tunisia. Plant Dis. 91:468.

Brewer, M. T., Rath, M., and Li, H. X. 2015. Genetic diversity and population structure of cucurbit gummy stem blight fungi based on microsatellite markers. Phytopathology 105:815-824.

Câmara, M. P., O'Neill, N. R., and van Berkum, P. 2002. Phylogeny of Stemphylium spp. based on ITS and glyceraldehyde-3-phosphate dehydrogenase gene sequences. Mycologia 94:660-672.

Carbone, I., and Kohn, L. M. 1999. A method for designing primer sets for speciation studies in filamentous ascomycetes. Mycologia 91:553-556.

Carneiro, G. A., Matić, S., Ortu, G., Garibaldi, A., Spadaro, D., and Gullino, M. L. 2017. Development and validation of a TaqMan real time PCR assay for the specific detection and quantification of Fusarium fujikuroi in rice plants and seeds. Phytopathology 107:885-892.

Champion, R. 1997. Identifier les champignons transmis par les semences. French National Institute for Agricultural Research, Paris, France.

Chehri, K., Salleh, B., Yli-Mattila, T., Reddy, K. R. N., and Abbasi, S. 2011. Molecular characterization of pathogenic Fusarium species in cucurbit plants from Kermanshah Province, Iran. Saudi J. Biol. Sci. 18:341-351.

Choi, Y. W., Hyde, K. D., and Ho, W. H. 1999. Single spore isolation of fungi. Fungal Divers. 3:29-38.

Cohen, Y., Rubin, A. E., Galperin, M., Ploch, S., Runge, F., and Thines, M. 2014. Seed transmission of Pseudoperonospora cubensis. PLoS One 9:e109766.

Corlett, M. 1981. A taxonomic survey of some species of Didymella and Didymella-like species. Can. J. Bot. 59:2016-2042.

Crous, P. W., Groenewald, J. Z., Risède, J. M., Simoneau, P., and Hywel-Jones, N. L. 2004. Calonectria species and their Cylindrocladium anamorphs: Species with sphaeropedunculate vesicles. Stud. Mycol. 50:415-430.

de Neergaard, E. 1989. Studies of Didytmella bryoniae (Auersw.) Rehm: Development in the host. J. Phytopathol. 127:107-115.

Dela Paz, M. A. G., Goodwin, P. H., Raymundo, A. K., Ardales, E. Y., and Vera Cruz, C. M. 2006. Phylogenetic analysis based on ITS sequences and conditions affecting the type of conidial germination of Bipolaris oryzae. Plant Pathol. 55: 756-765.

du Toit, L. J., Derie, M. L., and Hernandez-Perez, P. 2005. Verticillium wilt in spinach seed production. Plant Dis. 89:4-11

Duan, C.-X., Wang, X.-M., Zhu, Z.-D., and Wu, X.-F. 2007. Testing of seedborne fungi in wheat germ plasm conserved in the national crop gene bank of China. Agric. Sci. China 6:682-687.

El-Meleigi, M. A. 1991. Alternaria blossom-end rot and seedling blight of cucurbits in Al-Quassim. J. King Saud. Univ. 3:77-86.

El-Nagerabi, S., and Elshafie, E. 2001. Incidence of seed-borne fungi and aflatoxins in Sudanese lentil seeds. Mycopathologia 149:151-156.

Elmer, W. H. 2001. Seeds as vehicles for pathogen importation. Biol. Invasions 3: 263-271.

Farrag, E. S. H., and Moharam, M. H. A. 2012. Pathogenic fungi transmitted through cucumber seeds and safely elimination by application of peppermint extract and oil. Not. Sci. Biol. 4:83-91.

Fish, W. W., Bruton, B. D., and Popham, T. W. 2012. Cucurbit host range of Myrothecium roridum isolated from watermelon. Am. J. Plant Sci. 3:353-359.

Food and Agriculture Organization of the United Nations. 2016. FAOSTAT data. http://www.fao.org/faostat/en/\#data/QC

Gannibal, P. B. 2011. Alternaria cucumerina causing leaf spot of pumpkin newly reported in North Caucasus (Russia). New Dis. Rep. 23:36.

Glass, N. L., and Donaldson, G. 1995. Development of primer sets designed for use with PCR to amplify conserved genes from filamentous ascomycetes. Appl. Environ. Microbiol. 61:1323-1330.

Guillemette, T., Iacomi-Vasilescu, B., and Simoneau, P. 2004. Conventional and real-time PCR-based assay for detecting Alternaria brassicae in cruciferous seed. Plant Dis. 88:490-496.

Halfon-Meiri, A., and Rylski, I. 1983. Internal mold caused in sweet pepper by Alternaria alternata: Fungal ingress. Phytopathology 73:67-70.

Jeon, S. J., Nguyen, T. T. T., and Lee, H. B. 2015. Phylogenetic status of an unrecorded species of Curvularia, $C$. spicifera, based on current classification system of Curvularia and Bipolaris group using multi loci. Mycobiology 43:210-217.

Keinath, A. P. 2011. From native plants in central Europe to cultivated crops worldwide: The emergence of Didymella bryoniae as a cucurbit pathogen. HortScience 46:532-535.

Keinath, A. P., Farnham, M. W., and Zitter, T. A. 1995. Morphological pathological and genetic differentiation of Didymella bryoniae and Phoma spp. isolated from cucurbits. Phytopathology 85:364-369.

Kgatle, M. G., Truter, M., Ramusi, T. M., Flett, B., and Aveling, T. A. S. 2018. Alternaria alternata, the causal agent of leaf blight of sunflower in South Africa. Eur. J. Plant Pathol. 151:677-688.
Konstantinova, P., Bonants, P., van Gent-Pelzer, M., van der Zouwen, P., and van den Bulk, R. 2002. Development of specific primers for detection and identification of Alternaria spp. in carrot material by PCR and comparison with blotter and plating assays. Mycol. Res. 106:23-33.

Kusai, N. A., Azmi, M. M. Z., Zulkifly, S., Yusof, M. T., and Zainudin, N. A. I. M. 2015. Morphological and molecular characterization of Curvularia and related species associated with leaf spot disease of rice in Peninsular Malaysia. Fis. Acc. Lincei 27:205-214.

Lee, D. H., Mathur, S. B., and Neergard, P. 1984. Detection and location of seedborne inoculum of Didymella bryoniae and its transmission in seedlings of cucumber and pumpkin. Phytopathol. Z. 109:301-308.

Lombard, L., Houbraken, J., Decock, C., Samson, R. A., Meijer, M., Réblová, M., Groenewald, J. Z., and Crous, P. W. 2016. Generic hyper-diversity in Stachybotriaceae. Persoonia 36:156-246.

Lombard, L., van der Merwe, N. A., Groenewald, J. Z., and Crous, P. W. 2015. Generic concepts in Nectriaceae. Stud. Mycol. 80:189-245.

Majumder, D., Rajesh, T., Suting, E. G., and Debbarma, A. 2013. Detection of seed borne pathogens in wheat: Recent trends. Aust. J. Crop Sci. 7:500-507.

Mamgain, A., Roychowdhury, R., and Tah, J. 2013. Alternaria pathogenicity and its strategic controls. Res. J. Biol. 1:1-9.

Mancini, V., Murolo, S., and Romanazzi, G. 2016. Diagnostic methods for detecting fungal pathogens on vegetable seeds. Plant Pathol. 65:691-703.

Mancini, V., and Romanazzi, G. 2014. Seed treatments to control seedborne fungal pathogens of vegetable crops. Pest Manag. Sci. 70:860-868.

Mathur, S. B., and Kongsdal, O. 2003. Blotter method. Pages 104-313 in: Common Laboratory Seed Health Testing Methods for Detecting Fungi. International Seed Testing Association, Bassersdorf, Switzerland.

Mehl, H. L., and Epstein, L. 2007. Identification of Fusarium solani f. sp. cucurbitae race 1 and race 2 with PCR and production of disease-free pumpkin seeds. Plant Dis. 91:1288-1292.

Moumni, M., Mancini, V., Allagui, M. B., Murolo, S., and Romanazzi, G. 2019. Black rot of squash (Cucurbita moschata Duchesne) caused by Stagonosporopsis cucurbitacearum reported in Italy. Phytopathol. Mediterr. 58:379-383.

Orawan, P., Arm, U., and Unartngam, J. 2014. Effectiveness of Myrothecium roridum for controlling water hyacinth and species identification based on molecular data. Afr. J. Microbiol. Res. 8:1444-1452.

Özer, N., and Coskuntuna, A. 2016. The biological control possibilities of seedborne fungi. Pages 383-403 in: Current Trends in Plant Disease Diagnostics and Management Practices. P. Kumar, V. Kumar Gupta, A. Kumar Tiwari, and M. Kamle, eds. Springer, Cham, Switzerland.

Paul, N. C., Deng, J. X., Lee, H. B., and Yu, S. H. 2015. Characterization and pathogenicity of Alternaria burnsii from seeds of Cucurbita maxima (Cucurbitaceae) in Bangladesh. Mycobiology 43:384-391.

Peay, K. G., Kennedy, P. G., and Bruns, T. D. 2008. Fungal community ecology: A hybrid beast with a molecular master. Bioscience 58:799-810.

Pellegrino, C., Gilardi, G., Gullino, M. L., and Garibaldi, A. 2010. Detection of Phoma valerianellae in lamb's lettuce seeds. Phytoparasitica 38:159-165.

Petkar, A., and Ji, P. 2017. Infection courts in watermelon plants leading to seed infestation by Fusarium oxysporum f. sp. niveum. Phytopathology 107: 828-833.

Petzer, C. F. 1958. Leaf spot disease of muskmelon caused by Pleospora herbarum (PERS.) RABH. (Conidial stage Stemphylium botryosum WALLR.). S. Afr. J. Agric. Sci. 1:3-22.

Pryor, B. M., and Gilbertson, R. L. 2000. Molecular phylogenetic relationships amongst Alternaria species and related fungi based upon analysis of nuclear ITS and mtSSU rDNA sequences. Mycol. Res. 104:1312-1321.

Rennberger, G., Gerard, P., and Keinath, A. P. 2018. Occurrence of foliar pathogens of watermelon on commercial farms in South Carolina estimated with stratified cluster sampling. Plant Dis. 102:2285-2295.

Rennberger, G., and Keinath, A. P. 2018. Susceptibility of 14 new cucurbit species to gummy stem blight caused by Stagonosporopsis citrulli under field conditions. Plant Dis. 102:1365-1375.

Rodrigues, A. A. C., and Menezes, M. 2005. Identification and pathogenic characterization of endophytic Fusarium species from cowpea seeds. Mycopathologia 159:79-85.

Santos, G. R. D., Ferreira, M. A. D. S. V., Pessoa-Filho, M. A. C. P., Ferreira, M. E., and Café-Filho, A. C. 2009. Host specificity and genetic diversity of Didymella bryoniae from Cucurbitaceae in Brazil. J. Phytopathol. 157: 265-273.

Simmons, E. G. 1969. Perfect states of Stemphylium. Mycologia 61:1-26.

Somai, B. M., Keinath, A. P., and Dean, R. A. 2002. Development of PCR-ELISA for detection and differentiation of Didymella bryoniae from related Phoma species. Plant Dis. 86:710-716.

Stewart, J. E., Turner, A. N., and Brewer, M. T. 2015. Evolutionary history and variation in host range of three Stagonosporopsis species causing gummy stem blight of cucurbits. Fungal Biol. 119:370-382.

Sultana, N., and Ghaffar, A. 2009. Pathogenesis and control of Myrothecium spp. the cause of leaf spot on bitter gourd (Momordica charantia Linn.). Pak. J. Bot. $1: 429-433$.

Thomas-Sharma, S., Andrade-Piedra, J., Carvajal Yepes, M., Hernandez Nopsa, J. F., Jeger, M. J., Jones, R. A. C., Kromann, P., Legg, J. P., Yuen, J., Forbes, G. A., and Garrett, K. A. 2017. A risk assessment framework for 
seed degeneration: Informing an integrated seed health strategy for vegetatively propagated crops. Phytopathology 107:1123-1135.

Thompson, J. D., Higgins, D. G., and Gibson, T. J. 1994. CLUSTAL W: Improving the sensitivity of progressive multiple sequence alignment through sequence weighting, position-specific gap penalties and weight matrix choice. Nucleic Acids Res. 22:4673-4680.

Tsopmbeng, N. G., and Fomengia, D. N. 2015. Fungi associated with seeds of huckleberry (Solanum scabrum Mill.) grown in the western highlands of Cameroon. Int. J. Agric. Technol. 11:791-801.

Ünal, F., Turgay, E. B., Yıldırım, A. F., and Yüksel, C. 2011. First report of leaf blotch on sorghum caused by Bipolaris spicifera in Turkey. Plant Dis. 95:495.

Vakalounakis, D. J. 1990. Alternaria alternata f. sp. cucurbitae, the cause of a new leaf spot disease of melon (Cucumis melo). Ann. Appl. Biol. 117:507-513.

Vannacci, G., Sarrocco, S., and Porta-Puglia, A. 2014. Improved detection and monitoring of seed-borne fungal plant pathogens in Europe. Pages 67-85 in: Global Perspectives on the Health of Seeds and Plant Propagation Material. M. L. Gullino and G. Munkvold, eds. Springer, Dordrecht, Netherlands.

Varanda, C. M. R., Oliveira, M., Materatski, P., Landum, M., Clara, M. I. E., and Félix, M. D. R. 2016. Fungal endophytic communities associated to the phyllosphere of grapevine cultivars under different types of management. Fungal Biol. 120:1525-1536.

Walcott, R. R. 2003. Detection of seedborne pathogens. HortTechnology 13:40-47.
Walcott, R. R., McGee, D. C., and Misra, M. K. 1998. Detection of asymptomatic fungal infections of soybean seeds by ultrasound analysis. Plant Dis. 82:584-589.

Ward, E., Foster, S., Fraaije, B., and McCartney, H. A. 2004. Plant pathogen diagnostics: Immunological and nucleic acid-based approaches. Ann. Appl. Biol. 145:1-16.

White, T. J., Bruns, T., Lee, S., and Taylor, J. W. 1990. Amplification and direct sequencing of fungal ribosomal RNA genes for phylogenetics. Pages 315-322 in: PCR Protocols: A Guide to Methods and Applications. M. A. Innis, D. H. Gelfand, J. J. Sninsky, and T. J. White, eds. Academic Press, San Diego, CA.

Yao, X., Li, P., Xu, J., Zhang, M., Ren, R., Liu, G., and Yang, X. 2016. Rapid and sensitive detection of Didymella bryoniae by visual loop-mediated isothermal amplification assay. Front. Microbiol. 7:1372.

Ye, J., Coulouris, G., Zaretskaya, I., Cutcutache, I., Rozen, S., and Madden, T. 2012. Primer-BLAST: A tool to design target-specific primers for polymerase chain reaction. BMC Bioinformatics 13:134.

Zhang, S., Xiaoyu, Z., Yuxia, W., Jing, L., Xiuling, C., Aoxue, W., and Jingfu, L. 2012. Molecular detection of Fusarium oxysporum in the infected cucumber plants and soil. Pak. J. Bot. 4:1445-1451.

Zitter, T. A., and Kyle, M. M. 1992. Impact of powdery mildew and gummy stem blight on collapse of pumpkins (Cucurbita pepo. L.). Cucurbit Genet. Coop. 15 93-96. 